\title{
Synchronous Reluctance Motor vs. Induction Motor at Low-Power Industrial Applications: Design and Comparison
}

\author{
Nezih Gokhan Ozcelik, Ugur Emre Dogru, Murat Imeryuz and Lale T. Ergene *(D) \\ Electrical Engineering Department, Istanbul Technical University, 34469 Istanbul, Turkey; \\ ozceliknezih@gmail.com (N.G.O.); ugureemre.dogru@gmail.com (U.E.D.); imeryuz@itu.edu.tr (M.I.) \\ * Correspondence: ergenel@itu.edu.tr; Tel.: +90-212-285-3634
}

Received: 19 March 2019; Accepted: 4 June 2019; Published: 8 June 2019

\begin{abstract}
Although three-phase induction motors are the most common motor type in industry, a growing interest has arisen in emerging electric motor technologies like synchronous reluctance motors and permanent magnet motors. Synchronous reluctance motors are a step forward compared to permanent magnet motors when the cost of the system is considered. The main focus of this study is low-power industrial applications, which generally use three-phase induction motors. In this study, the synchronous reluctance motor family is compared at three different power levels: $2.2 \mathrm{~kW}, 4 \mathrm{~kW}$, and $5.5 \mathrm{~kW}$. The aim of this study is to design and compare synchronous reluctance motors, which can be alternative to the reference induction motors. Finite element analysis is performed for the reference induction motors initially. Their stators are kept the same and the rotors are redesigned to satisfy output power requirements of the induction motors. Detailed design, analysis, and optimization processes are applied to the synchronous reluctance motors considering efficiency, power density, and manufacturing. The results are evaluated, and the optimized designs are chosen for each power level. They are prototyped and tested to measure their performance.
\end{abstract}

Keywords: synchronous reluctance motor; induction motor; finite element method; synchronous motor; reluctance motor

\section{Introduction}

Increasing attention to energy efficiency makes electric motor technology important when considering the percentage of their energy consumption. Different types of electric motors are used in low-power industrial applications dependent on the needs of the system. However, market research shows that a great majority of industrial motors are still induction motors. Permanent magnet motors and synchronous reluctance motors are becoming an alternative solution for low-power industrial applications. Even though permanent magnet motors are more efficient compared to induction motors, their cost is still higher because of the permanent magnet. Demagnetization is another drawback of permanent magnet machines. Synchronous reluctance motors (SynRMs) have become prominent since the rotor does not have any conductor or any permanent magnet. It costs almost the same as the induction motor, and its efficiency is higher at the same power ratings.

There are many studies on synchronous reluctance machines in the literature. Kostko published the first paper titled "Polyphase Reaction Synchronous Motors" in 1923 [1]. The theory of synchronous reluctance machine was established the first time in this paper. However, SynRM was not an alternative to industrial induction machines in those days due to the lack of starting capacities and relatively low efficiencies. Cruickshank et al. published a paper titled "Axially Laminated Anisotropic Rotors for Reluctance Motors" and they proposed the axially laminated SynRM structure [2]. This motor was 
more efficient than Kostko's first design and became popular between the 1960s and 1970s because of its increased capabilities. The axial alignment of laminations required new special production lines, so this type of motor was not industrially viable in terms of manufacturing. Cruickshank et al. formed the mathematical theory of the axially laminated SynRM in another study [3]. In this work, it is shown that axially laminated SynRMs are still a little behind the induction machines even though they have higher saliency ratios than the transverse laminated SynRM. Honsinger formed the general analytical model of SynRM in his paper titled "The Inductances $L_{d}$ and $L_{q}$ of Reluctance Machines" in 1971 [4]. A new analytical method was proposed to calculate the axes inductances in this paper. Before this study, obtaining high saliency ratios, and eventually, higher torque, were arbitrary. SynRM became popular because of the developments in power electronics and manufacturing technologies in 1990s. Lipo proposed the synchronous reluctance motor as a viable alternative for AC drive systems [5]. As Lipo and Matsuo's research focused on rotor design optimization [6], Miller et al. studied driver designs for SynRM [7-9]. Vagati et al. had a paper on the design criteria of synchronous reluctance motors [10]. Vagati et al. had also a study on the experimental comparison of induction and synchronous reluctance motors. They showed that a SynRM can produce $20 \%$ to $40 \%$ higher torque compared to an IM in the case of the increased rated current for the same power loss or same temperature [11]. Another comparison of these two motors for a traction application was evaluated by Kamper et al. [12]. There are studies carried out only to maximize the saliency ratio [13]. Different optimization methodologies were evaluated by researchers. Moghaddam et al. evaluated the optimization of barrier shapes [14-16], Bianchi et al. focused on torque ripple reduction [17], and Lin et al. applied multi-objective optimization algorithms to a six-phase synchronous reluctance machine to increase the efficiency [18]. A paper was written by Kamper et al. which remarked on the importance of the finite element method (FEM) to analyze the SynRM [19]. Another work focusing on the multi-objective optimization algorithm of synchronous reluctance motors was published by Cupertino et al. [20]. Ergene et al. published a paper on a permanent magnet assisted SynRM (PMaSynRM), which is designed and prototyped for home appliance [21].

In this study, the rotors of the synchronous reluctance motors are designed for three different frames: $2.2 \mathrm{~kW}, 4 \mathrm{~kW}$, and $5.5 \mathrm{~kW}$. The stators of the SynRMs are kept the same as those of the reference induction motors at the same frames. The designed synchronous reluctance motors are prototyped and compared to the reference induction motors in terms of efficiency, losses, power density, active material, etc.

\section{Torque Equations}

The synchronous reluctance motor does not have a permanent magnet and conductor in its rotor compared to the permanent magnet motor and induction motor. The torque is equal to the reluctance torque, which is produced by saliency between $\mathrm{d}$ and $\mathrm{q}$ axes inductances. The ratio between $\mathrm{d}$ and $\mathrm{q}$ axes inductances is defined as the saliency ratio. This ratio directly affects the torque production of the synchronous reluctance motor. The general torque equation of this motor is in Equation (1) as [21]:

$$
\mathrm{T}=\frac{3}{2} \frac{\mathrm{p}}{2}\left(\lambda_{\mathrm{qs}} \mathrm{i}_{\mathrm{ds}}-\lambda_{\mathrm{ds}} \mathrm{i}_{\mathrm{qs}}\right)
$$

where $\mathrm{p}$ is the pole pair number, $\lambda_{\mathrm{ds}}, \lambda_{\mathrm{qs}}$ are $\mathrm{d}$ and $\mathrm{q}$ axis stator flux linkages, $\mathrm{i}_{\mathrm{ds}}, \mathrm{i}_{\mathrm{qs}}$ are $\mathrm{d}$ and $\mathrm{q}$ axis stator currents. Rotor currents are zero at steady-state, so the flux linkages can be expressed as a function of $d-q$ axis inductances $L_{d}$ and $L_{q}$, respectively, as given in Equations (2) and (3).

$$
\begin{aligned}
& \lambda_{\mathrm{ds}}=\mathrm{L}_{\mathrm{ds}} \mathrm{i}_{\mathrm{ds}} \\
& \lambda_{\mathrm{qs}}=\mathrm{L}_{\mathrm{qs}} \mathrm{i}_{\mathrm{qs}}
\end{aligned}
$$


The reluctance torque in d-q inductances are given in Equation (4).

$$
\mathrm{T}=\frac{3}{2} \frac{\mathrm{p}}{2}\left(\mathrm{~L}_{\mathrm{ds}}-\mathrm{L}_{\mathrm{qs}}\right) \mathrm{i}_{\mathrm{ds}} \mathrm{i}_{\mathrm{qs}}
$$

The saliency ratio between the $\mathrm{L}_{\mathrm{d}}$ and $\mathrm{L}_{\mathrm{q}}$ inductances has a vital role in obtaining higher torque values.

\section{Design Methodology and Parameters}

The design methodology consists of three main stages: Electromagnetic, structural, and thermal designs. These design stages are given in Figure 1 as blocks, and each main block affects each other. Design criteria block is the input for the electromagnetic design. The electromagnetic design block includes motor sizing, optimizing, and finite element analysis of the optimized motor design. Ergene et al proposed a multi-parameter chart, including rotor geometric parameters for $2.2 \mathrm{~kW}$ motor [22]. At the end of the electromagnetic design procedure, a structural design procedure begins. The procedure supplies feedback to previous design procedures and updates the design following the same design steps, respectively.

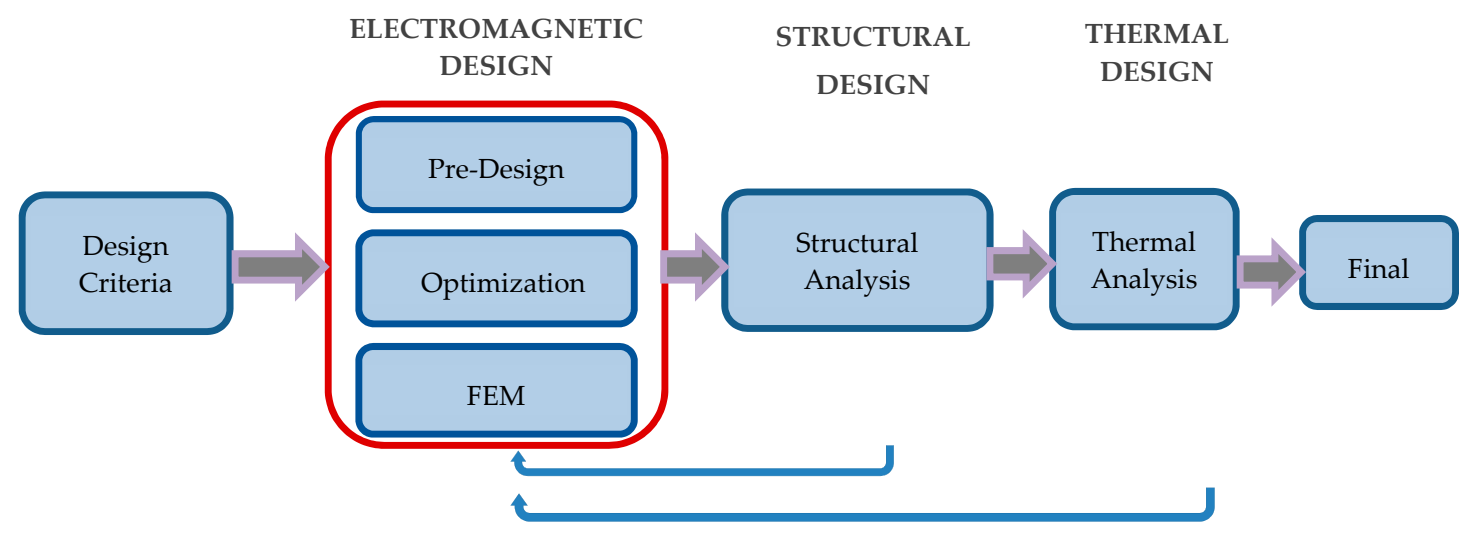

Figure 1. Electric motor design procedure.

In this study, the reference induction motors and the newly designed synchronous reluctance motors are compared for three different power levels at $2.2 \mathrm{~kW}, 4 \mathrm{~kW}$, and $5.5 \mathrm{~kW}$ for low-power industrial applications. The stators and ampere-turns of the induction motors are kept the same during synchronous reluctance motors design procedures to make a fair comparison. The rotors of the induction motors are designed again considering the reluctance motor parameters. The design procedure steps are given in Figure 2 schematically.

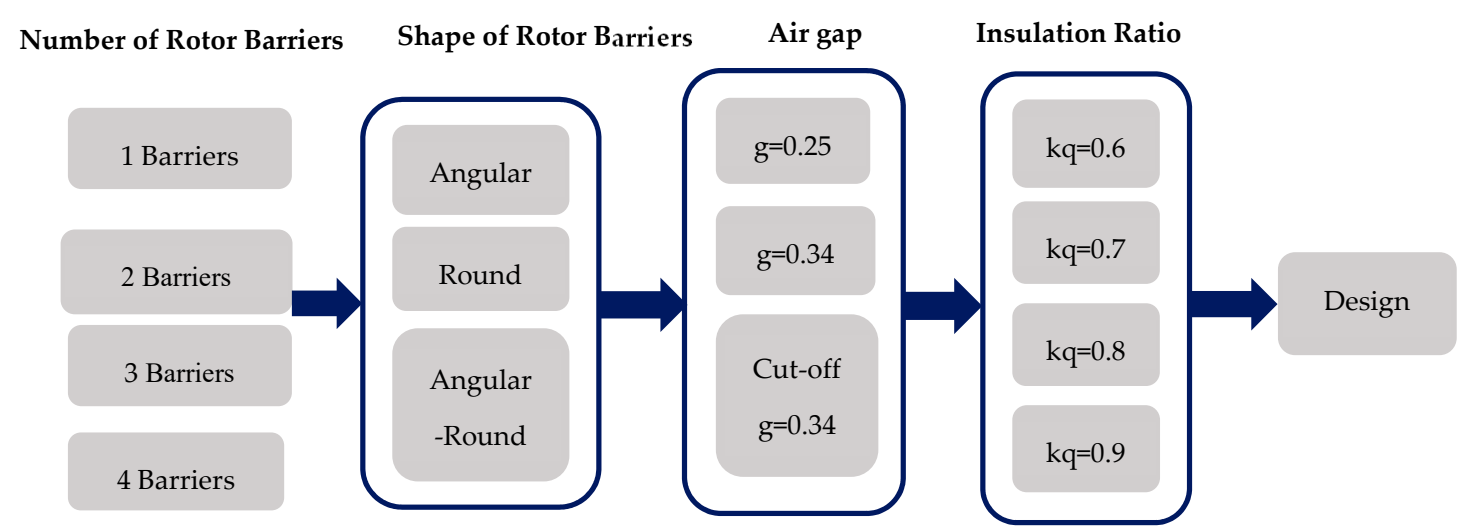

Figure 2. Synchronous reluctance motor (SynRM) electromagnetic design parameters. 
In the design step, the rotor barrier effect is analyzed by considering a different number of rotor barriers and shapes. The air gap is also a parameter, although the stator dimensions and the ampere-turns are kept the same. Uniform and salient air gap structures with different radial air gap lengths are considered for the design. Lastly, the insulation ratios of the synchronous reluctance motors are evaluated. Efficiency, cost, and power density of each design are compared to those of the reference induction motor to obtain the optimum design for low-power industrial applications, such as pumps and fans.

\section{Multi Parameter Design Steps of SynRMs}

The parameters, such as barrier number, end bridge thickness, air gap dimension, and insulation ratio, are used on the motor model in FEA to obtain an optimized motor in terms of cost, efficiency, and serial production limits [22]. The rotor design parameters are shown in Figure 3.

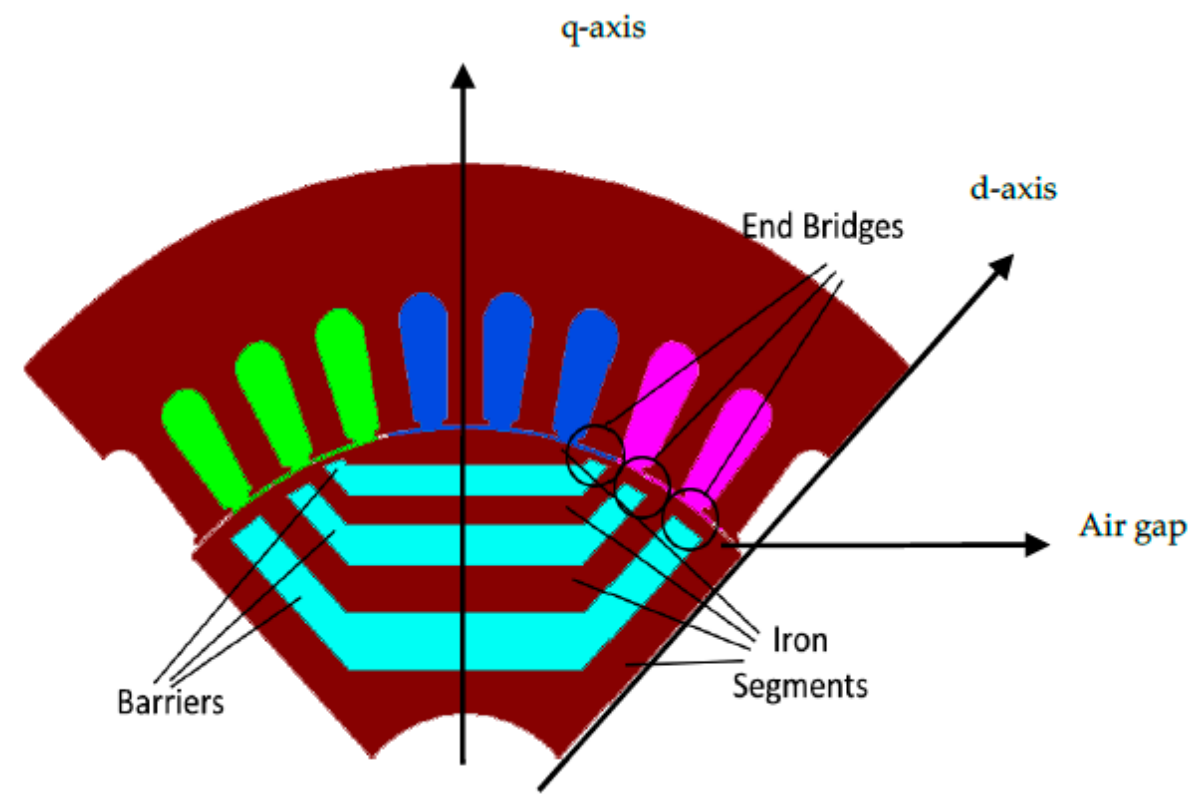

Figure 3. SynRM design parameters.

Some constraints are imposed on each step. The outer and inner stator diameter, the winding distribution, the stator slot number, the stator, and rotor material are defined as constant in the analysis. Specific constraints are only used on certain steps. The barrier number parameter is examined first. The thickness effect of end bridges is analyzed for two flux barriers. The $\mathrm{L}_{\mathrm{d}} / \mathrm{L}_{\mathrm{q}}$ ratio varies due to both the flux barriers' numbers and their shape. Another parameter analyzed is the flux barrier width variation. It is gradually decreased in the outward radial direction. The air gap effect is evaluated in three different models. Two of them are the uniform air gap in the radial direction, and the third model is the cut-off. Each air gap model is employed on two different numbers of barriers and three different flux barrier structure. The insulation ratio is the final parameter for the simulations. This ratio directly influences the saliency ratio $\left(\mathrm{L}_{\mathrm{d}} / \mathrm{L}_{\mathrm{q}}\right)$. Four different insulation ratios are examined on four different flux barrier motor models with variable and constant width angular flux barriers.

\section{Finite Element Analysis Results}

\subsection{Analysis of the Reference Induction Motors}

The reference induction motors have $2.2 \mathrm{~kW}, 4 \mathrm{~kW}$ and $5.5 \mathrm{~kW}$ rated power values as listed in Table 1 . These induction motors are the mass production commercial type squirrel cage induction motors. The rated voltage is $400 \mathrm{~V}$ (line-to-line) for $2.2 \mathrm{~kW}$ motor, while it is $690 \mathrm{~V}$ for the $4 \mathrm{~kW}$ and 
$5.5 \mathrm{~kW}$ motors. The current must be increased to provide the same amount of power if the voltage is $400 \mathrm{~V}$ for 4.4 and $5.5 \mathrm{~kW}$. The motor faces danger if the current exceeds the motor's nameplate ratings.

Table 1. Reference Induction Motors' Nameplate.

\begin{tabular}{|c|c|c|c|}
\hline Power (kW) & 5.5 & 4 & 2.2 \\
\hline Voltage $(\mathrm{V})$ & $400 / 690$ & $400 / 690$ & $230 / 400$ \\
\hline Current (A) & $11.1 / 6.4$ & $8.3 / 4.8$ & $8.5 / 4.9$ \\
\hline Frequency $(\mathrm{Hz})$ & 50 & 50 & 50 \\
\hline Number of Poles & 4 & 4 & 4 \\
\hline Speed $\left(\min ^{-1}\right)$ & 1465 & 1455 & 1450 \\
\hline Slip & 0.0233 & 0.03 & 0.033 \\
\hline Efficiency (\%) & 89.6 & 88.6 & 86.7 \\
\hline
\end{tabular}

First, the numerical models of the motors are built using a two dimensional (2D) finite element method (FEM) based commercial software (FLUX2D) with 2D time-stepping vector potential formulation. The 3D effects like the end turns of stator winding are included using lumped circuit parameters in the software. The lumped circuit parameters of the motors are calculated using SIEMENS-SPEED software (V11.04.010, SPEED Laboratory, University of Glasgow, Glasgow, Scotland), which is an analytical motor modelling tool. The outputs are injected to FEM. Whole motor geometries are considered for numerical accuracy.

Both the rotor and stator laminations' magnetic material are Cogent SURA M700 35A silicon steel for these three motors, and its magnetic flux density and magnetic field intensity values are shown in Figure 4a. Only the $5.5 \mathrm{~kW}$ induction motor has a double cage rotor, as the other two motors have deep rotor bars. The mesh of the $4 \mathrm{~kW}$ reference induction motor is given in Figure $4 \mathrm{~b}$.

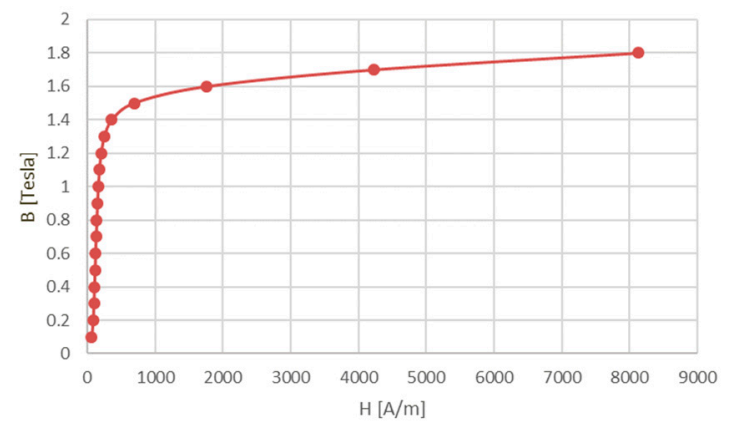

(a)

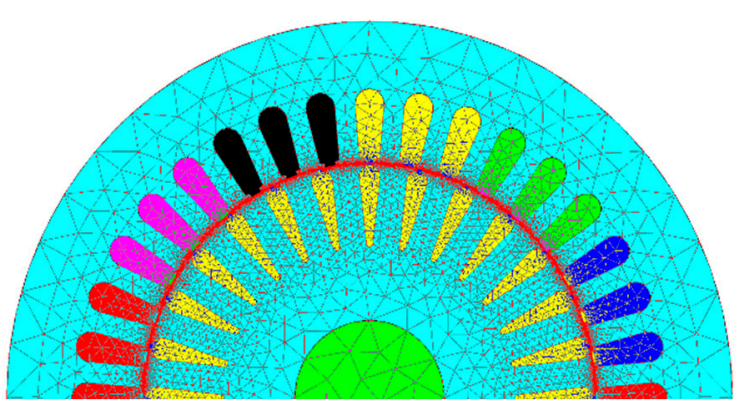

(b)

Figure 4. (a) B-H curve of the M700 Si-steel; (b) The mesh discretization of $4 \mathrm{~kW}$ motor.

The equi-flux lines showing the four-pole distribution and color shade of flux densities at $t=0.3 \mathrm{~s}$ for the three reference induction motors are given in Figure 5.

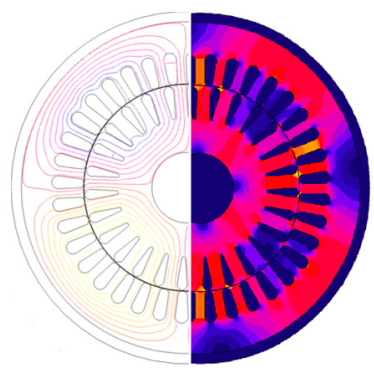

(a)

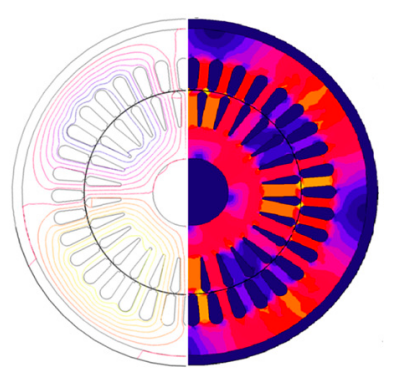

(b)

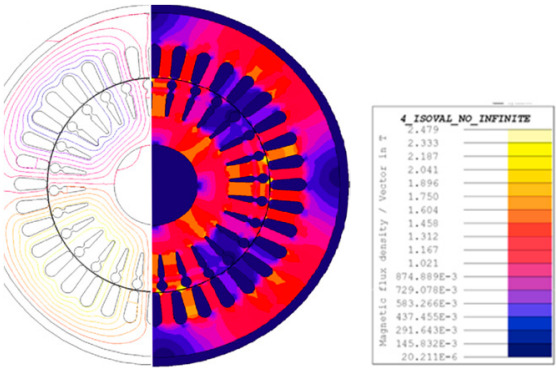

(c)

Figure 5. The equi-flux lines and flux densities of (a) $2.2 \mathrm{~kW}$, (b) $4 \mathrm{~kW}$, and (c) $5.5 \mathrm{~kW}$ Induction motors. 
The normal components of the air gap flux densities for a geometrical cycle at $t=0.5 \mathrm{~s}$ and the torque profiles of the motors are presented in Figure 6 for the rated load at the rated voltage and speed given in Table 1. Four pole distributions with the slotting from Figure $6 \mathrm{a}, \mathrm{c}, \mathrm{e}$ can be easily seen for each motor.

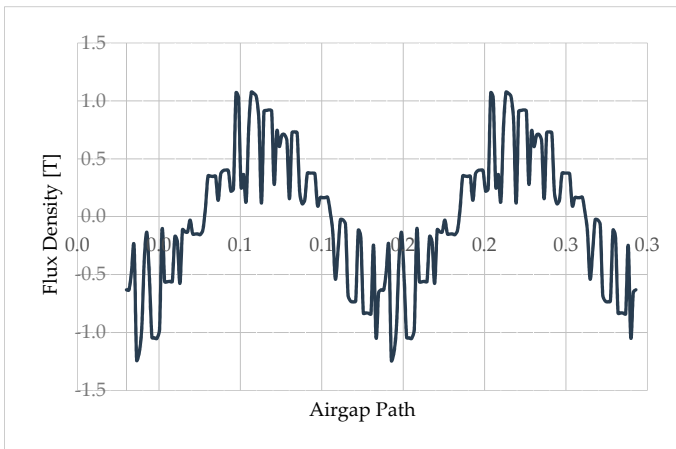

(a)

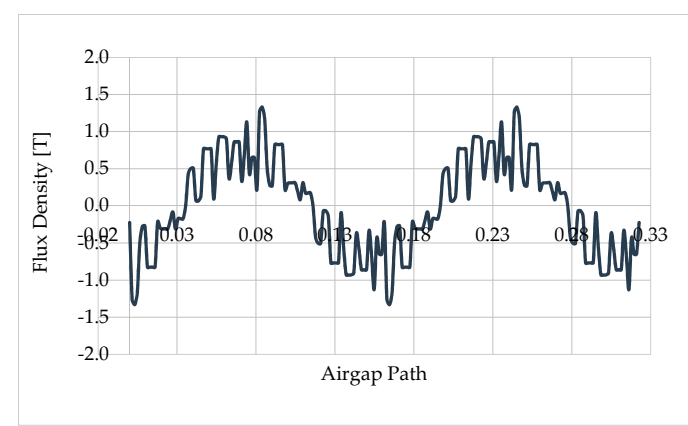

(c)

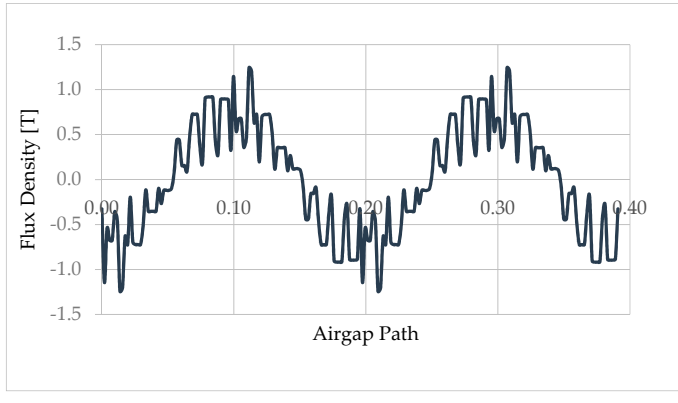

(e)

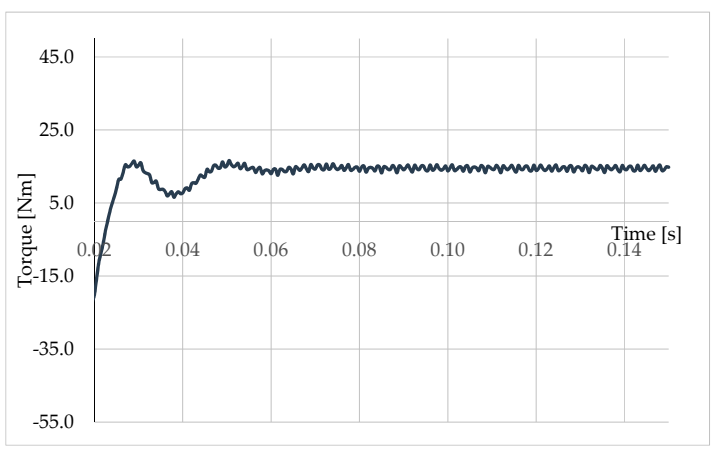

(b)

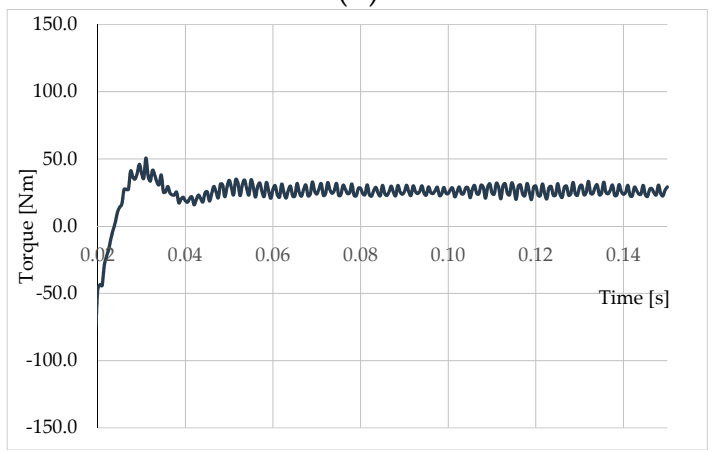

(d)

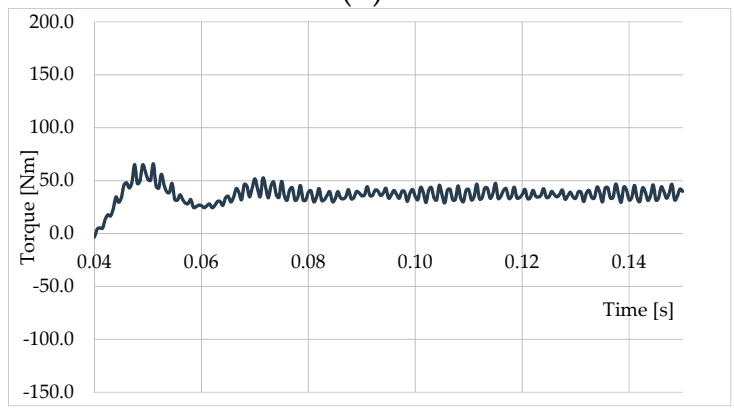

(f)

Figure 6. The normal component of the flux density in the air gap (a) $2.2 \mathrm{~kW}$, (c) $4 \mathrm{~kW}$, and (e) $5.5 \mathrm{~kW}$ motors and torque variation of (b) $2.2 \mathrm{~kW}$, (d) $4 \mathrm{~kW}$, and (f) $5.5 \mathrm{~kW}$ motors.

The FEM analysis results of the motors are compared to the test results to validate the motor FEM models. The test bed for the motor tests is given in Figure 7. The test bed has a reference induction motor, hysteresis eddy current brake, and measurement system.

The no-load and rated load tests are performed due to the IEC standard 60034-2-1. The stator resistances are obtained as given in Table 2. Eight different voltage (1.1, 1, 0.95, 0.9, 0.6, 0.5, 0.4, 0.3 times of the rated voltage) are applied and measured for the no-load test. No-load stator current and no-load input power are measured for each voltage. The first four voltages $(1.1,1.0,0.95 ; 0.90$ times of the rated voltage $)$ are used to calculate the iron losses $\left(\mathrm{P}_{\mathrm{fe}}\right)$. The last four $(0.60,0.50,0.40,0.30$ times of the rated voltage) are used to calculate the friction and windage losses $\left(\mathrm{P}_{\mathrm{fw}}\right)$. The no-load test measurements and calculated loss terms are given in Tables $3-5$ for $2.2 \mathrm{~kW}, 4 \mathrm{~kW}$, and $5.5 \mathrm{~kW}$ reference motors, respectively. 


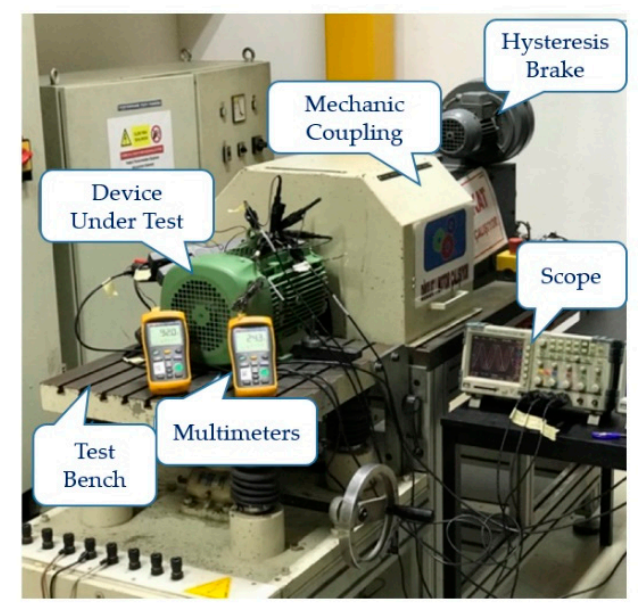

Figure 7. Test bench.

Table 2. Stator resistances per phase for the reference induction motors.

\begin{tabular}{ccccc}
\hline \multirow{2}{*}{ Power } & \multicolumn{2}{c}{ Initial Condition } & \multicolumn{2}{c}{ Thermal Regime } \\
\cline { 2 - 5 } & Temperature $\left({ }^{\circ} \mathbf{C}\right)$ & Resistance (Ohms) & Temperature $\left({ }^{\circ} \mathbf{C}\right)$ & Resistance $($ Ohms) \\
\hline $2.2 \mathrm{~kW}$ & 22 & 1.91 & 64.1 & 2.196 \\
$4 \mathrm{~kW}$ & 22 & 2.35 & 72.8 & 3.159 \\
$5.5 \mathrm{~kW}$ & 22 & 1.32 & 67 & 1.603 \\
\hline
\end{tabular}

Table 3. No-Load Test results of $2.2 \mathrm{~kW}$ induction motor.

\begin{tabular}{cccccc}
\hline $\mathbf{V}(\mathbf{V})$ & $\mathbf{V}^{\mathbf{2}}$ & $\mathbf{I}(\mathbf{A})$ & $\mathbf{P}_{\mathbf{0}}(\mathbf{W})$ & $\mathbf{P}_{\mathbf{c u} 0}(\mathbf{W})$ & $\mathbf{P}_{\mathbf{f e}}+\mathbf{P}_{\mathbf{f w 0}} \mathbf{( W )}$ \\
\hline 120 & 14,400 & 0.86 & 43 & 4.9 & 38.1 \\
160 & 25,600 & 1.13 & 55 & 8.5 & 46.5 \\
200 & 40,000 & 1.43 & 70 & 13.5 & 56.5 \\
240 & 57,600 & 1.73 & 88 & 19.6 & 68.4 \\
305 & 93,025 & 2.28 & 124 & 34.1 & 89.9 \\
370 & 136,900 & 3.02 & 178 & 60.2 & 117.8 \\
400 & 160,000 & 3.49 & 210 & 80.1 & 129.9 \\
435 & 189,225 & 4.22 & 271 & 117.5 & 153.5 \\
\hline
\end{tabular}

Table 4. No-Load Test results of $4 \mathrm{~kW}$ induction motor.

\begin{tabular}{cccccc}
\hline $\mathbf{V}(\mathbf{V})$ & $\mathbf{V}^{\mathbf{2}}$ & $\mathbf{I}(\mathbf{A})$ & $\mathbf{P}_{\mathbf{0}}(\mathbf{W})$ & $\mathbf{P}_{\mathbf{c u} \mathbf{0}}(\mathbf{W})$ & $\mathbf{P}_{\mathbf{f e}}+\mathbf{P}_{\mathbf{f w 0}}(\mathbf{W})$ \\
\hline 120 & 14,400 & 0.95 & 36 & 8.6 & 27.4 \\
160 & 25,600 & 1.49 & 48 & 21 & 27 \\
200 & 40,000 & 1.81 & 68 & 31 & 36.9 \\
240 & 57,600 & 2.24 & 93 & 47.5 & 45.4 \\
305 & 93,025 & 3.01 & 140 & 85.8 & 54.2 \\
370 & 136,900 & 4.1 & 210 & 159.3 & 50.69 \\
400 & 160,000 & 4.7 & 263 & 209.3 & 53.7 \\
435 & 189,225 & 5.4 & 366 & 276.3 & 89.7 \\
\hline
\end{tabular}


Table 5. No-Load Test results of $5.5 \mathrm{~kW}$ induction motor.

\begin{tabular}{cccccc}
\hline $\mathbf{V}(\mathbf{V})$ & $\mathbf{V}^{\mathbf{2}}$ & $\mathbf{I}(\mathbf{A})$ & $\mathbf{P}_{\mathbf{0}}(\mathbf{W})$ & $\mathbf{P}_{\mathbf{c u} 0}(\mathbf{W})$ & $\mathbf{P}_{\mathbf{f e}}+\mathbf{P}_{\mathbf{f w} \mathbf{0}}(\mathbf{W})$ \\
\hline 120 & 14,400 & 1.6 & 68 & 12.3 & 55.7 \\
160 & 25,600 & 2.1 & 88 & 21 & 67 \\
200 & 40,000 & 2.63 & 120 & 33.3 & 86.7 \\
240 & 57,600 & 3.22 & 151 & 49.8 & 101.2 \\
305 & 93,025 & 4.26 & 213 & 87 & 126 \\
370 & 136,900 & 5.62 & 298 & 151.8 & 146.2 \\
400 & 160,000 & 6.47 & 349 & 201.3 & 147.7 \\
435 & 189,225 & 8.07 & 434 & 312.9 & 121.1 \\
\hline
\end{tabular}

The load curve test is performed after the thermal regime of winding temperatures is achieved. There are six operating points due to the standard: $1.25,1.15,1,0.75,0.5,0.25$ times of the rated load are performed. The input power, $\mathrm{P}_{\text {in }}$; output torque, $\mathrm{T}_{\text {out }}$; stator line current, $\mathrm{I}_{1}$; phase-to-phase voltage, $\mathrm{V}$; and speed, $\mathrm{n}$; measurements should be taken for each loading test. The load test results are given for the reference motors in Tables $6-8$, respectively. The output powers for the motors are calculated using the measured output torque and speed.

Table 6. Load Test results of $2.2 \mathrm{~kW}$ IM.

\begin{tabular}{|c|c|c|c|c|c|c|}
\hline Parameters & $25 \%$ & $50 \%$ & $75 \%$ & $100 \%$ & $115 \%$ & $125 \%$ \\
\hline Voltage V $(\mathrm{V})$ & 402 & 401 & 401 & 401 & 400 & 401 \\
\hline Phase Current $\mathrm{I}_{1}(\mathrm{~A})$ & 3.5 & 3.82 & 4.37 & 4.92 & 5.83 & 6.72 \\
\hline Input Power $P_{\text {in }}(W)$ & 771 & 1336 & 1943 & 2560 & 3187 & 3822 \\
\hline Torque T $(\mathrm{Nm})$ & 3.6 & 7.3 & 10.9 & 14.6 & 18.2 & 21.9 \\
\hline Speed $\mathrm{n}\left(\mathrm{min}^{-1}\right)$ & 1487 & 1473 & 1458 & 1445 & 1427 & 1410 \\
\hline Output Power $P_{\text {out }}(W)$ & 560 & 1126 & 1663 & 2208 & 2718 & 3232 \\
\hline Efficiency & 72.7 & 84.2 & 85.6 & 86.3 & 85.3 & 84.6 \\
\hline
\end{tabular}

Table 7. Load Test results of $4 \mathrm{~kW}$ IM.

\begin{tabular}{|c|c|c|c|c|c|c|}
\hline Parameters & $25 \%$ & $50 \%$ & $75 \%$ & $100 \%$ & $115 \%$ & $125 \%$ \\
\hline Voltage V (V) & 402 & 400 & 401 & 401 & 400 & 401 \\
\hline Phase Current $\mathrm{I}_{1}(\mathrm{~A})$ & 5.19 & 5.88 & 6.91 & 8.22 & 9.73 & 11.41 \\
\hline Input Power $P_{\text {in }}(\mathrm{W})$ & 1264 & 2327 & 3415 & 4500 & 5655 & 6819 \\
\hline Torque $\mathrm{T}(\mathrm{Nm})$ & 6.6 & 13.2 & 19.8 & 26.3 & 32.9 & 39.5 \\
\hline Speed $\mathrm{n}\left(\mathrm{min}^{-1}\right)$ & 1491 & 1480 & 1466 & 1457 & 1439 & 1426 \\
\hline Output Power $\mathrm{P}_{\text {out }}(\mathrm{W})$ & 1030 & 2045 & 3038 & 4011 & 4955 & 5896 \\
\hline Efficiency & 81.5 & 88 & 89 & 89.1 & 87.6 & 86.5 \\
\hline
\end{tabular}

Table 8. Load Test results of $5.5 \mathrm{~kW}$ IM.

\begin{tabular}{|c|c|c|c|c|c|c|}
\hline Parameters & $25 \%$ & $50 \%$ & $75 \%$ & $100 \%$ & $115 \%$ & $125 \%$ \\
\hline Voltage V (V) & 402 & 400 & 399 & 400 & 401 & 400 \\
\hline Phase Current $\mathrm{I}_{1}(\mathrm{~A})$ & 6.74 & 7.77 & 9.27 & 11.1 & 13.11 & 15.24 \\
\hline Input Power $P_{\text {in }}(\mathrm{W})$ & 1701 & 3161 & 4632 & 6122 & 7652 & 9188 \\
\hline Torque T $(\mathrm{Nm})$ & 9.1 & 18.1 & 27.2 & 36.2 & 45.3 & 54.3 \\
\hline Speed $\mathrm{n}\left(\mathrm{min}^{-1}\right)$ & 1491 & 1484 & 1476 & 1467 & 1455 & 1445 \\
\hline Output Power $\mathrm{P}_{\text {out }}(\mathrm{W})$ & 1420 & 2814 & 4202 & 5558 & 6899 & 8213 \\
\hline Efficiency & 83.5 & 89 & 90.7 & 90.8 & 90.2 & 89.4 \\
\hline
\end{tabular}

The FEM and test results of the reference induction motors are given in Table 9 in terms of the torque, current, power, and efficiency for the rated values. The difference between FEM and test results are in a $10 \%$ range and are acceptable. 
Table 9. Induction Motors' FEM and TEST results.

\begin{tabular}{ccccccc}
\hline Parameter & $\mathbf{2 . 2} \mathbf{~ k W ~ F E M ~}$ & $\mathbf{2 . 2} \mathbf{~ k W}$ Test & $\mathbf{4} \mathbf{~ k W ~ F E M ~}$ & $\mathbf{4} \mathbf{~ k W ~ T e s t}$ & $\mathbf{5 . 5} \mathbf{~ k W ~ F E M ~}$ & $\mathbf{5 . 5} \mathbf{~ k W}$ Test \\
\hline Torque $(\mathrm{Nm})$ & 14.6 & 14.5 & 26.26 & 26.3 & 36.1 & 36.2 \\
Current $\left(\mathrm{A}_{\text {rms }}\right)$ & 4.8 & 4.95 & 8 & 8.22 & 11.1 & 11.7 \\
Output Power $(\mathrm{W})$ & 2215 & 2203 & 3957 & 3984 & 5535 & 5482 \\
Efficiency $(\%)$ & 86 & 86.3 & 89.53 & 89.1 & 89.8 & 90.8 \\
\hline
\end{tabular}

\subsection{Analysis of Synchronous Reluctance Motors}

After the analysis of the reference induction motors, synchronous reluctance motor models are built in three power ratings for the multi-parameter analyses and their cross-effect analyses at the same time. Complete motor models are used to obtain high precision during pre-modelling and post-processing steps as in induction motor models.

Graphical illustrations of the rotor barrier numbers and barrier shapes considered for the numerical analysis are given in Figure 8. The number of flux barriers is analyzed to evaluate the influence on the performance of the motor. The finite element analysis is performed up to four flux barriers since flux barriers saturate after six, and $\mathrm{L}_{\mathrm{d}}-\mathrm{L}_{\mathrm{q}}$ inductances show no difference. Three flux barrier shapes are evaluated. Rotor barrier number illustrations are given a to $\mathrm{d}$ for barrier number 1 to 4 , accordingly, at section (A) and barrier shape illustrations are given e to $\mathrm{h}$ for angular, round, angular-round, and cut-off, accordingly, in Figure 8. The iron guides form an angle with the flux barriers at the angular (A) barrier shape. Off-centered round pieces create iron flux guides at the round (R) flux barriers. Angular-round (A-R) is the last design, which is a combination of the angular and round barriers.

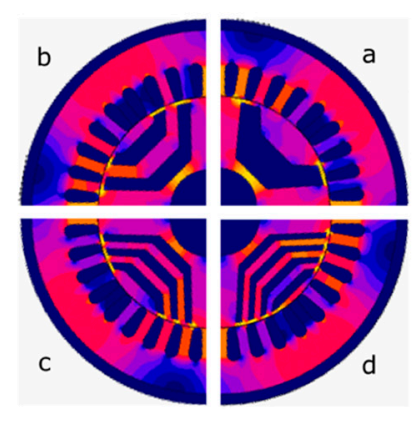

(A)
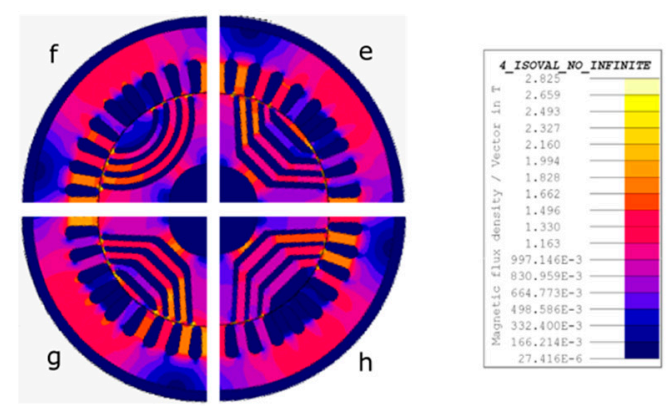

(B)

Figure 8. SynRM design parameters (A The number of rotor barriers per pole: (a) one barrier, (b) two barriers, (c) three barriers, (d) four barriers, B Barrier Shape: (e) angular, (f) round, (g) angular-round, (h) cut-off).

The torque characteristic results at rated load are given in Figure 9. The torque ripple due to the number of flux barriers are listed in Table 10.

Table 10. Output Torques and their ripples due to the rotor barriers' number for $2.2 \mathrm{~kW}$ SynRM motor.

\begin{tabular}{ccccc}
\hline Parameter & 1 Barrier & 2 Barriers & 3 Barriers & 4 Barriers \\
\hline Torque $(\mathrm{Nm})$ & 15.1 & 17.9 & 19.1 & 24.4 \\
Torque Ripple $(\%)$ & 77 & 46 & 41 & 27 \\
\hline
\end{tabular}




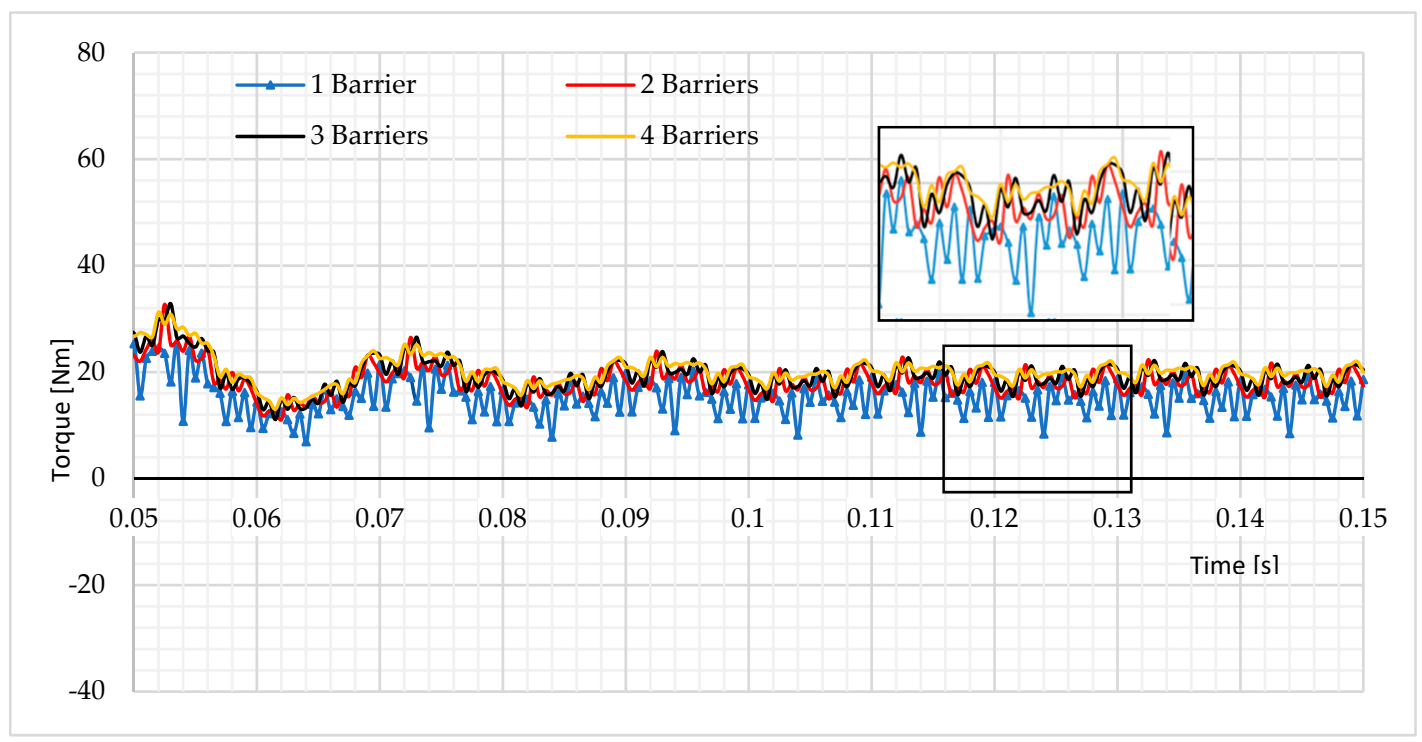

Figure 9. Torque profiles of the $2.2 \mathrm{~kW}$ SynRM due to the number of rotor barriers (Data from [22]).

The rotor structure is not very strong mechanically due to the flux barriers. The tangential end bridges are designed to reinforce the rotor as shown in Figure 3. Making end bridges very thin results in problems for manufacturing processes. Increasing the end bridge thickness of the rotor causes the torque decrease. The output torque graph for the six different structures is given in Figure 10. The normal components of flux densities for end bridge thickness are given in Figure 11. Also, the comparative torque and flux density results are given in Table 11.

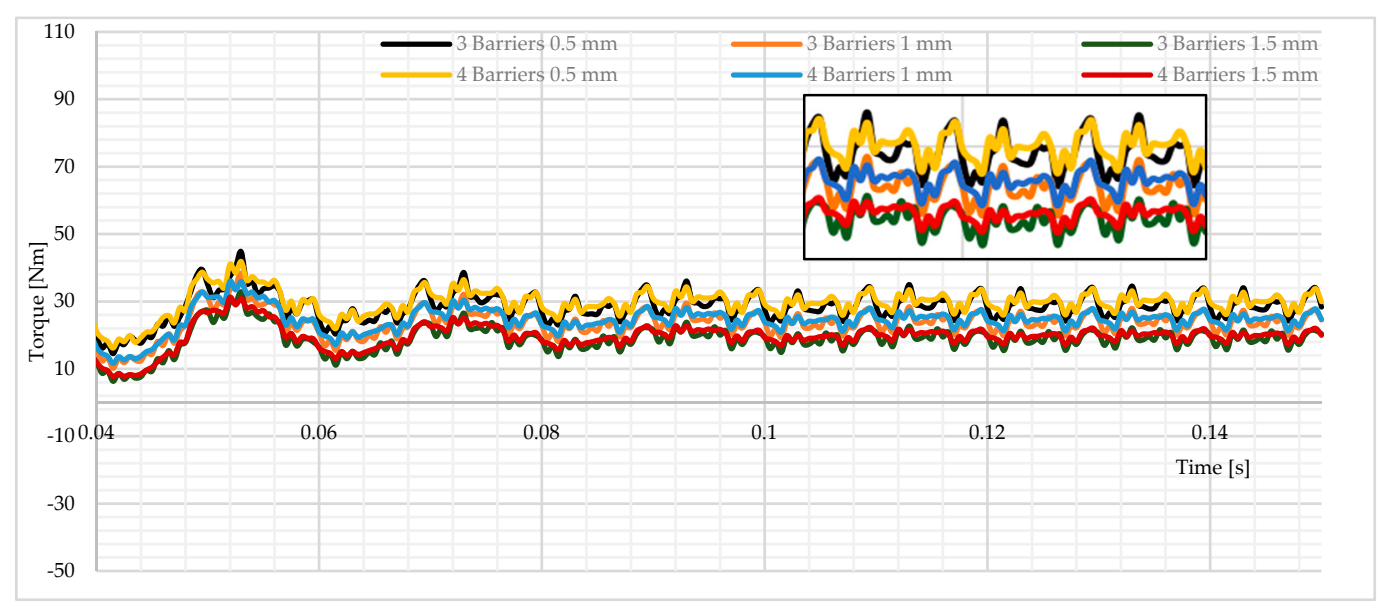

Figure 10. Torque outputs of $2.2 \mathrm{~kW}$ SynRM due to different end thicknesses for three and four barriers (Data from [22]).

Table 11. Air Gap Flux Densities and average output torque of $2.2 \mathrm{~kW}$ SynRM due to different end thicknesses for three and four barriers.

\begin{tabular}{ccccccc}
\hline Parameter & \multicolumn{3}{c}{ 3 Barriers } & \multicolumn{3}{c}{ 4 Barriers } \\
\hline Thickness $(\mathrm{mm})$ & 0.5 & 1 & 1.5 & 0.5 & 1 & 1.5 \\
Flux Density (T) & 0.78 & 0.78 & 0.78 & 0.79 & 0.78 & 0.78 \\
Torque $(\mathrm{Nm})$ & 28.9 & 23.9 & 19 & 29.9 & 24.7 & 19.8 \\
\hline
\end{tabular}




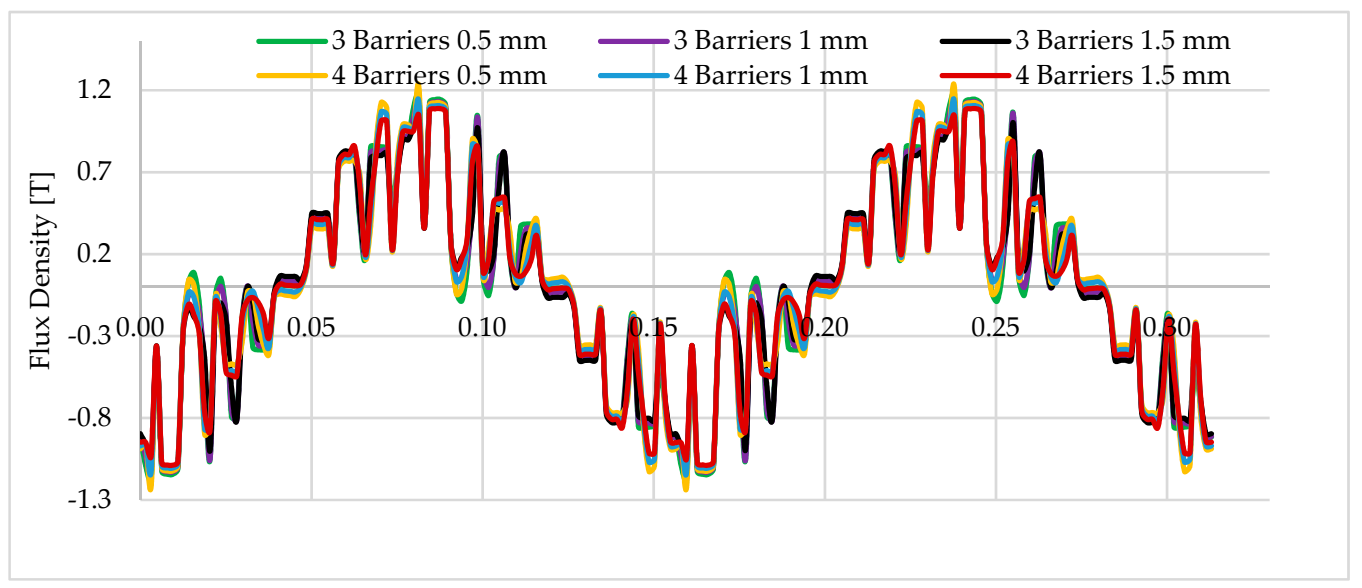

Figure 11. Air gap flux density of $2.2 \mathrm{~kW}$ SynRM due to different end thicknesses (Data from [22]).

The radial air gap width should be proposed as small as possible by considering the mechanical limitations. The air gap can be uniform or cut-off in the radial direction for the synchronous reluctance motor designs. The flux density, average output torque, and torque ripple for different air gap values are evaluated in detail in Figures 12 and 13, respectively.

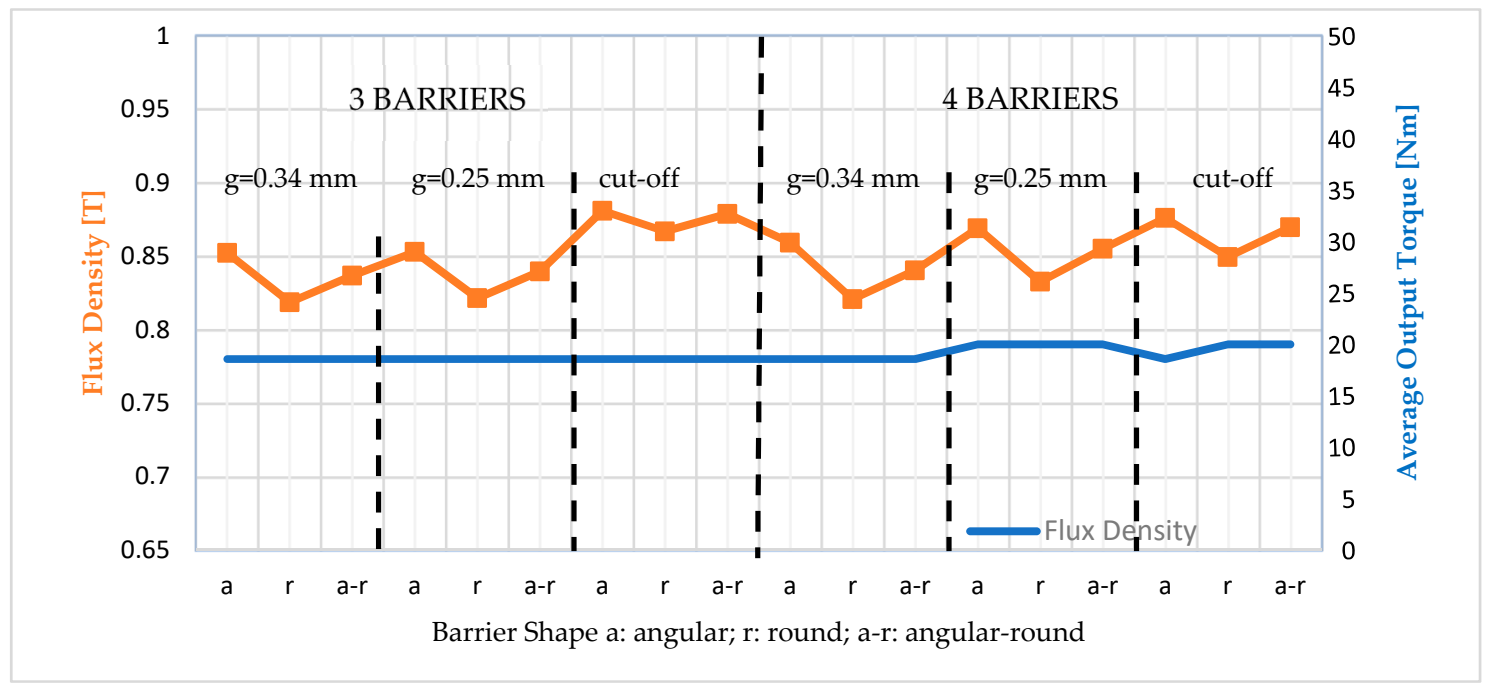

Figure 12. Flux density and average torque of $2.2 \mathrm{~kW}$ SynRM for different number of barriers and air gap values.

The ratio of the sum of flux barrier widths to the sum of iron guide widths in the q-axis direction is defined as 'insulation ratio', $\mathrm{k}_{\mathrm{q}}$. If the rotor is completely made of iron without any saliency, the $\mathrm{k}_{\mathrm{q}}$ would be equal to 0 . If the total flux barrier width is equal to that of iron segment width, then $\mathrm{k}_{\mathrm{q}}$ is equal to 1 . Output torque characteristics of the synchronous reluctance motors are presented in Figure 14. They are operated at the rated load with rated voltage and speed values given in Table 1. The average values at steady state and torque ripples as percentage are summarized in Table 12. 


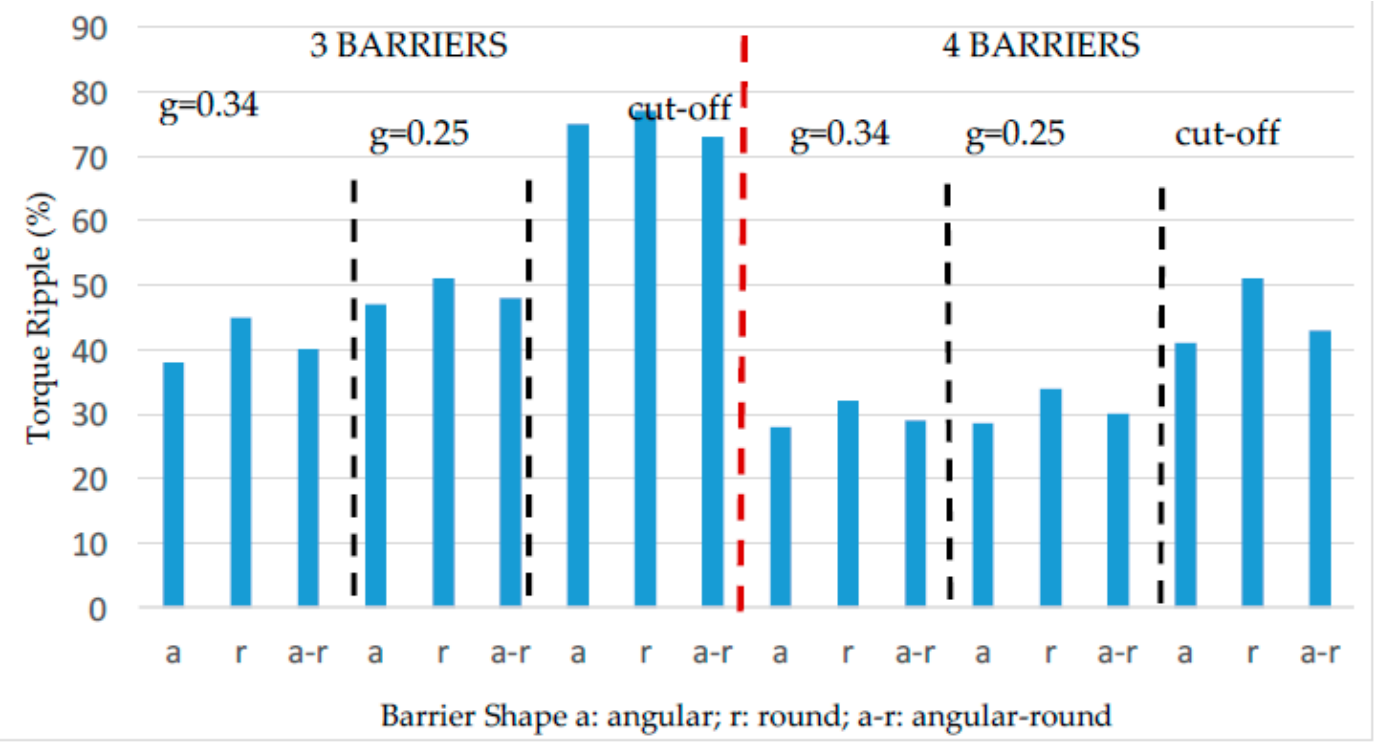

Figure 13. Torque ripple of $2.2 \mathrm{~kW}$ SynRM for different number of barriers and air gap values.

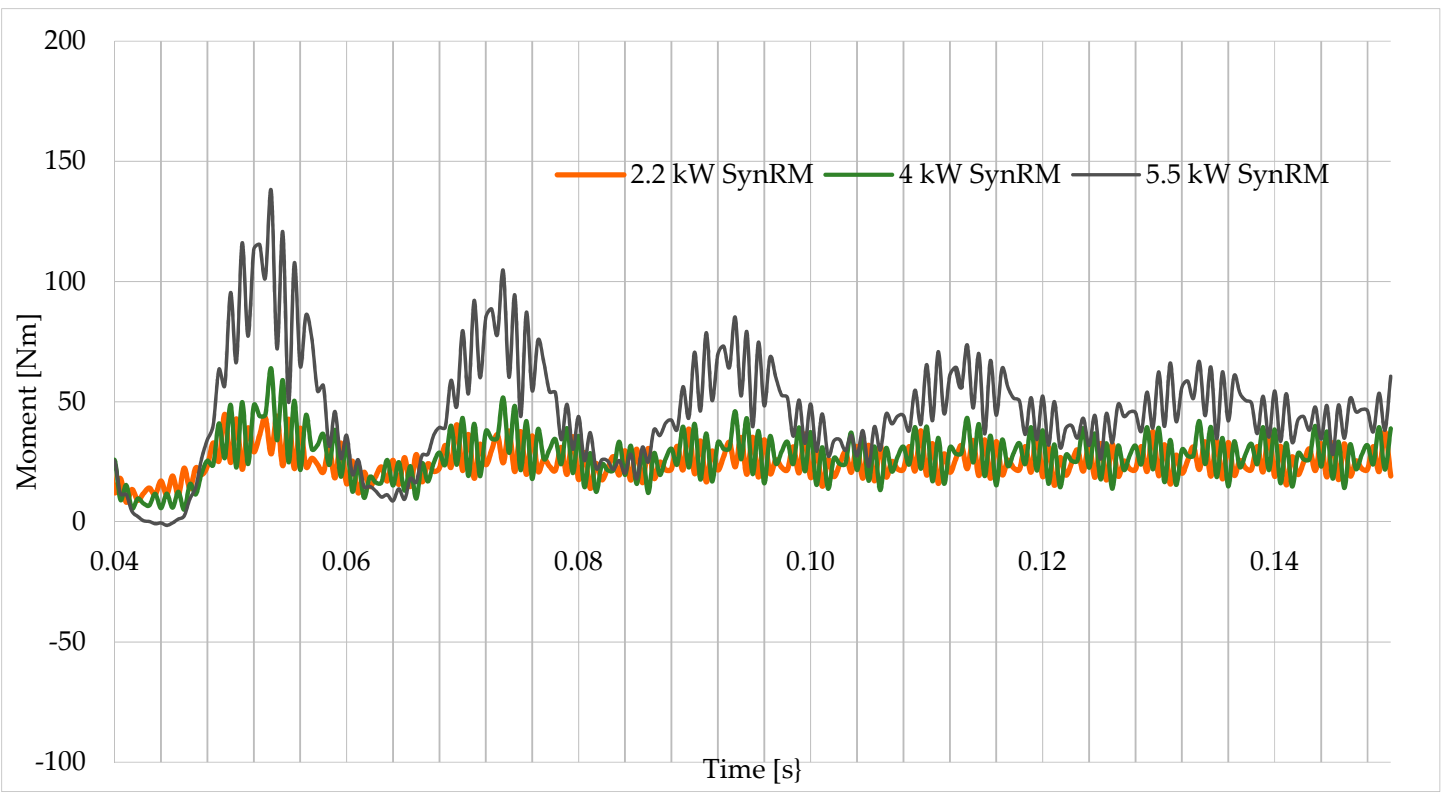

Figure 14. The output torque variation for different power levels.

Table 12. Average Output Torques and their torque ripples for SynRM at different power ratings.

\begin{tabular}{cccc}
\hline \multirow{2}{*}{ Parameter } & \multicolumn{3}{c}{$\mathbf{4}$ Barriers } \\
\cline { 2 - 4 } & $\mathbf{2 . 2} \mathbf{~ k W}$ & $\mathbf{4} \mathbf{~ k W}$ & $\mathbf{5 . 5} \mathbf{~ k W}$ \\
\hline Torque $(\mathrm{Nm})$ & 14.1 & 25.2 & 35.03 \\
Torque Ripple $(\%)$ & 18 & 17 & 22 \\
\hline
\end{tabular}

Structural analysis of the newly designed motors is another important issue to be considered. The stress analysis of the prototyped motors is simulated in ANSYS in order to satisfy the motor's mechanical integrity. The simulation is performed at $1500 \mathrm{~min}^{-1}$ and the mechanic characteristics of the rotor are given in Table 13. 
Table 13. Mechanical Characteristics of Rotor Si-Steel.

\begin{tabular}{cc}
\hline Parameters & M700 \\
\hline Mass Density $\left(\mathrm{kg} / \mathrm{m}^{3}\right)$ & 7800 \\
Young Modulus $(\mathrm{GPa})$ & 210 \\
Poisson Coefficient & 0.31 \\
Tensile Yield Strength $(\mathrm{MPa})$ & 300 \\
Tensile Ultimate Strength $(\mathrm{MPa})$ & 410 \\
\hline
\end{tabular}

The mechanical analysis is performed to see the total deformation and the equivalent stress on the rotor under the rated operation condition. The simulations and results for total deformation of $2.2 \mathrm{~kW}$ motor are given in Figure 15 and Table 14, respectively. The minimum total deformation and maximum elastic strain values are listed for one and four barriers. A four-barrier structure is more robust than a single barrier with the safety factor of 12.217.

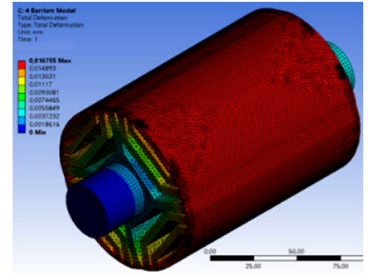

(a)

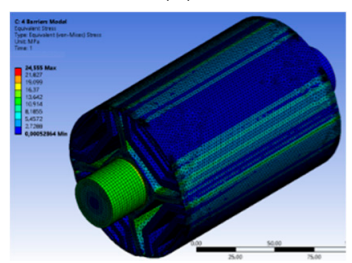

(e)

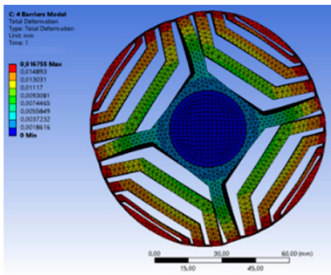

(b)

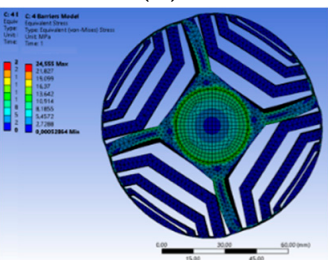

(f)

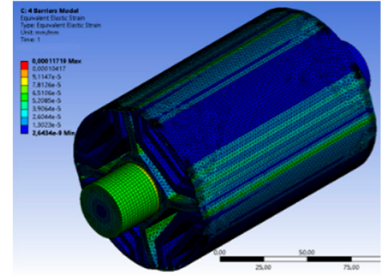

(c)

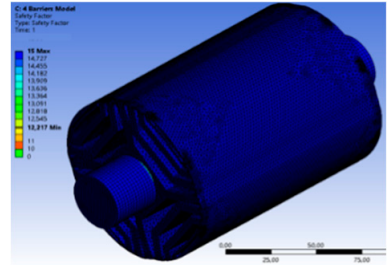

(g)

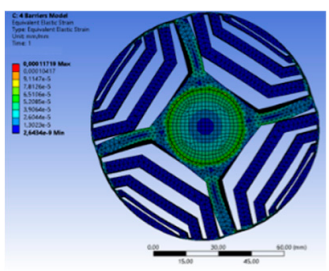

(d)

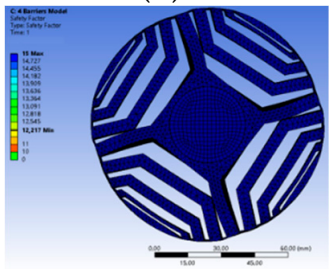

(h)

Figure 15. Structural analysis of $2.2 \mathrm{~kW}$ motor with four-rotor barrier per pole (a) total deformation (axial view), (b) total deformation (radial view), (c) Equivalent Elastic Strain (axial view), (d) Equivalent Elastic Strain (radial view), (e) Equivalent Stress (axial view), (f) Equivalent Stress (radial view), (g) Safety Factor (axial view), (h) Safety Factor (radial view).

Table 14. Structural analysis results of $2.2 \mathrm{~kW}$ motor.

\begin{tabular}{ccc}
\hline Parameter & 1 Barrier & 4 Barriers \\
\hline Maximum Total Deformation $(\mu \mathrm{m})$ & 29.296 & 16.755 \\
Maximum Elastic Strain $(\mathrm{mm} / \mathrm{mm})$ & $1.942 \times 10^{-4}$ & $1.1719 \times 10^{-4}$ \\
Maximum Stress $(\mathrm{MPa})$ & 25,424 & 24,555 \\
Minimum Safety Factor & 64.525 & 12.217 \\
Maximum Safety Factor & 15 & 15 \\
\hline
\end{tabular}

\section{Prototype Synchronous Reluctance Motors}

The overall results are evaluated after the multi-parameter design process. The synchronous reluctance models for prototyping are chosen considering technical parameters like efficiency, torque ripple, production process, etc. The same stator, fan, and housing frames of the reference induction motors are used for newly designed synchronous reluctance motors. Rotor laminations are produced by using wire erosion cut. The lamination structure and motor views for three different power levels are given in Figures 16 and 17a, accordingly. 

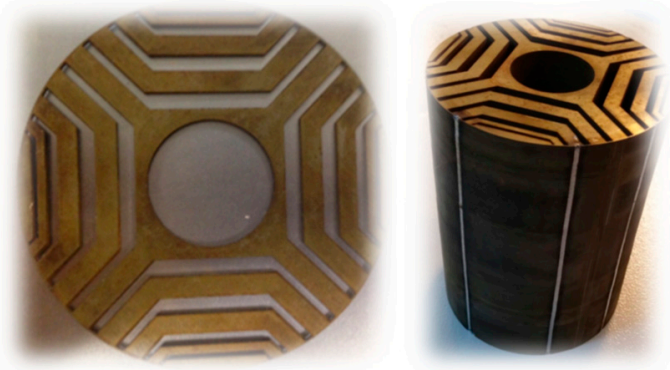

Figure 16. Prototype motor sample lamination and the rotor [22].

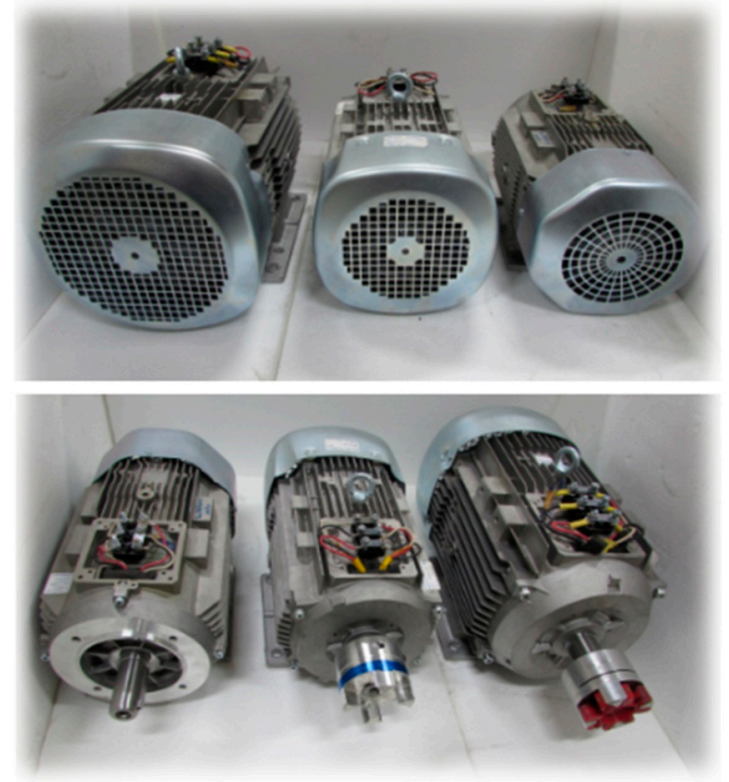

(a)

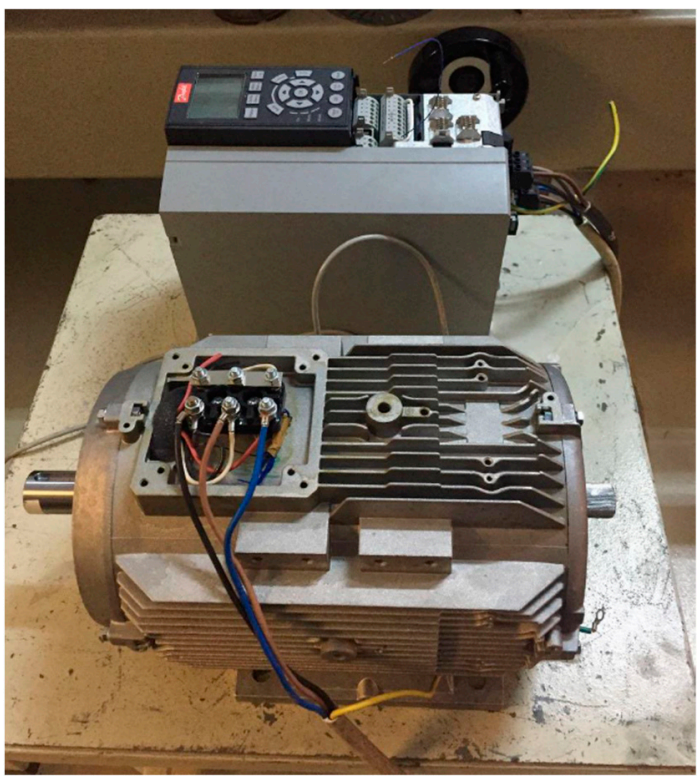

(b)

Figure 17. (a) Prototype SynRM Motors at $5.5 \mathrm{~kW}, 4 \mathrm{~kW}$, and $2.2 \mathrm{~kW}$; (b) Prototype motor and its driver.

The ideal motor model achieved from multi-parametric FEM analyses is the angular four variable-width barriers rotor that has $\mathrm{k}_{\mathrm{q}}=1$ insulation ratio. The $4-\mathrm{kW}$ prototyped motor and its test set are shown in Figure 17b. The test system has a generic variable frequency motor driver. The inverter is supplied by a variable AC source. However, the input voltage of the inverter is fixed during the test. In the inverter operating menu, the output power and speed level of the motors are set to the required rated output. The inverter sets the speed and output power of the device under the test. Two power analyzers are used for the measurements in the test systems. The first one is located between the variable AC source and the inverter, and the second one is located between the inverter and the motor. Thus, the motor efficiency, inverter efficiency, and system efficiency can be obtained separately. As a result, SynRM efficiency is calculated by direct measurement of converter output power, corresponding to motor input power $\left(\mathrm{P}_{\text {in }}\right)$ and the mechanical power output at the motor shaft $\left(\mathrm{P}_{\text {mech }}\right)$. The test system has a torque sensor to measure the output torque of motor. The measurement is performed due to the IEC standards 60034-2-3 loading test. Six operating points are performed due to the standard: $1.25,1.15,1,0.75,0.5$, and 25 times of the rated load at the rated speed. The input power, $\mathrm{P}_{\text {in }}$; output torque, $\mathrm{T}_{\text {out }}$; stator line current; $\mathrm{I}_{1}$; phase-to-phase voltage, $\mathrm{V}$; and speed, $\mathrm{n}$; measurements are taken for each loading. The load test results are given in Tables 15-17 for $2.2 \mathrm{~kW}$, $4 \mathrm{~kW}$, and $5.5 \mathrm{~kW}$ SynRMs, respectively. 
Table 15. Load Test results of $2.2 \mathrm{~kW}$ SynRM.

\begin{tabular}{ccccccc}
\hline Parameters & $\mathbf{2 5 \%}$ & $\mathbf{5 0 \%}$ & $\mathbf{7 5 \%}$ & $\mathbf{1 0 0} \%$ & $\mathbf{1 1 5 \%}$ & $\mathbf{1 2 5 \%}$ \\
\hline Voltage V $(\mathrm{V})$ & 396.6 & 436.5 & 455.5 & 452.1 & 453.8 & 450.3 \\
Phase Current $\mathrm{I}_{1}(\mathrm{~A})$ & 2.34 & 3.25 & 4.03 & 4.91 & 5.95 & 7.16 \\
${\text { Input Power } \mathrm{P}_{\text {in }}(\mathrm{W})}$ & 651 & 1275 & 1887 & 2490 & 3159 & 3843 \\
Torque T $(\mathrm{Nm})$ & 3.52 & 7.04 & 10.56 & 14.1 & 17.6 & 21.1 \\
Speed n $\left(\mathrm{min}^{-1}\right)$ & 1500 & 1500 & 1500 & 1500 & 1500 & 1500 \\
Output Power $\mathrm{P}_{\text {out }}(\mathrm{W})$ & 553.1 & 1106 & 1659 & 2212 & 2765 & 3318 \\
Efficiency & 85 & 86.8 & 87.9 & 88.9 & 87.6 & 86.4 \\
\hline
\end{tabular}

Table 16. Load Test results of $4 \mathrm{~kW}$ SynRM.

\begin{tabular}{ccccccc}
\hline Parameters & $\mathbf{2 5 \%}$ & $\mathbf{5 0 \%}$ & $\mathbf{7 5 \%}$ & $\mathbf{1 0 0} \%$ & $\mathbf{1 1 5 \%}$ & $\mathbf{1 2 5 \%}$ \\
\hline Voltage V (V) & 461 & 469 & 485 & 478 & 457 & 473 \\
Phase Current $\mathrm{I}_{1}(\mathrm{~A})$ & 3.84 & 5.59 & 7.14 & 8.8 & 10.9 & 13.38 \\
${\text { Input Power } \mathrm{P}_{\text {in }}(\mathrm{W})}$ & 1147 & 2240 & 3326 & 4413 & 5540 & 6745 \\
Torque T $(\mathrm{Nm})$ & 6.38 & 12.75 & 19.13 & 25.5 & 31.88 & 38.26 \\
Speed n $\left(\mathrm{min}^{-1}\right)$ & 1500 & 1500 & 1500 & 1500 & 1500 & 1500 \\
Output Power $\mathrm{P}_{\text {out }}(\mathrm{W})$ & 1001.5 & 2003 & 3004.6 & 4006.1 & 5007.7 & 6009.2 \\
Efficiency & 87.3 & 89.4 & 90.3 & 90.8 & 90.4 & 89.1 \\
\hline
\end{tabular}

Table 17. Load Test results of $5.5 \mathrm{~kW}$ SynRM.

\begin{tabular}{cccccc}
\hline Parameters & $\mathbf{2 5 \%}$ & $\mathbf{5 0} \%$ & $\mathbf{7 5 \%}$ & $\mathbf{1 0 0 \%}$ & $\mathbf{1 1 5 \%}$ \\
\hline Voltage V $(\mathrm{V})$ & 485 & 457 & 469 & 469.4 & 462 \\
Phase Current $\mathrm{I}_{1}(\mathrm{~A})$ & 5.34 & 7.61 & 9.59 & 11.8 & 13.79 \\
${\text { Input Power } \mathrm{P}_{\text {in }}(\mathrm{W})}_{\text {Torque } \mathrm{T}(\mathrm{Nm})}^{1580}$ & 3052 & 4571 & 6013 & 7067 \\
Speed n $\left(\right.$ min $\left.^{-1}\right)$ & 1500 & 17.64 & 26.46 & 35.3 & 42.56 \\
Output Power $\mathrm{P}_{\text {out }}(\mathrm{W})$ & 1387 & 2770 & 4156 & 5550 & 6501 \\
Efficiency & 87.8 & 90.8 & 90.9 & 92.3 & 92 \\
\hline
\end{tabular}

Since the rated output power levels have been desired to be constant, the input voltage of SynRMs are obtained slightly higher than the rated values of IMs as given in Tables 15-17.

\section{Comparative Results}

In this section, the comparative results are given for the reference induction motors and newly designed synchronous reluctance motors for three different power ranges.

\subsection{Performance}

Table 18 shows the general motor parameters for both induction motors and synchronous reluctance motors at the rated speed and torque. The torque is slightly different since the output power is the same and the speeds are naturally different.

Table 18. Comparative Measured Performance Results (Frame-Size-Power Range).

\begin{tabular}{|c|c|c|c|c|c|c|}
\hline \multirow[t]{2}{*}{ Parameter } & \multicolumn{2}{|c|}{$\begin{array}{c}2.2 \mathrm{~kW} \text { (4 Pole) } \\
100 \text { Frame }\end{array}$} & \multicolumn{2}{|c|}{$\begin{array}{l}4 \text { kW (4 Pole) } \\
112 \text { Frame }\end{array}$} & \multicolumn{2}{|c|}{$\begin{array}{c}5.5 \mathrm{~kW} \text { (4 Pole) } \\
132 \text { Frame }\end{array}$} \\
\hline & IM & SynRM & IM & SynRM & IM & SynRM \\
\hline Voltage (V) & 400 & 452.1 & 400 & 478 & 400 & 469.4 \\
\hline Current (A) & 4.95 & 4.91 & 8.3 & 8.8 & 11.1 & 11.8 \\
\hline Speed $\left(\min ^{-1}\right)$ & 1450 & 1500 & 1455 & 1500 & 1465 & 1500 \\
\hline Torque $(\mathrm{Nm})$ & 14.48 & 14 & 26.25 & 25.46 & 35.85 & 35.01 \\
\hline $\cos \theta$ & 0.78 & 0.647 & 0.79 & 0.6 & 0.79 & 0.6 \\
\hline
\end{tabular}


The reference IMs and newly designed SynRMs are forced to start with full load condition to determine the starting capability of the motors. As a result, the motors can start at full load condition for each power rating with no problems. The controller is not designed by the authors. The prototyped SynRM motors are driven by a generic commercial controller. There were no problems either for starting or operating.

Torque vs current graphs of IMs and SynRMs are given Figure 18. These data sets are evaluated under $1500 \mathrm{~min}^{-1}$ for SynRMs and near $1500 \mathrm{~min}^{-1}$ for IMs.

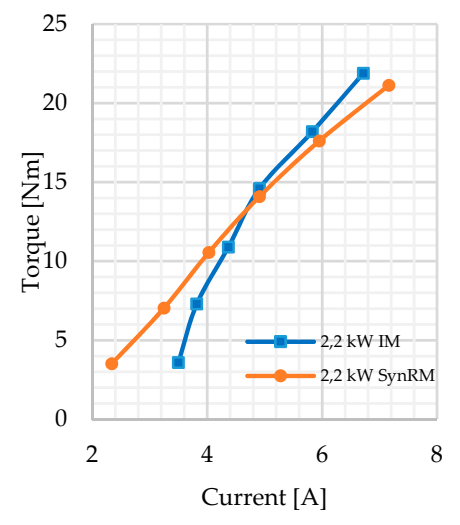

(a)

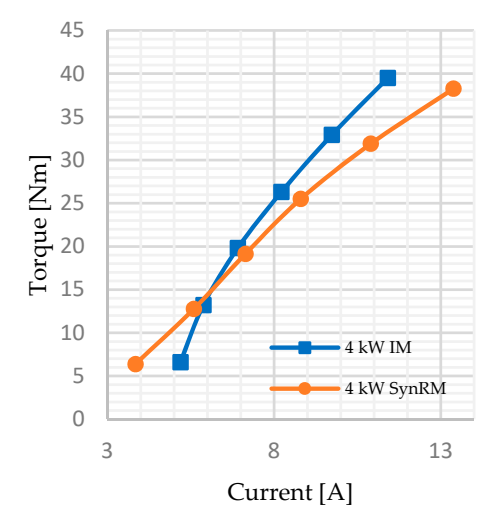

(b)

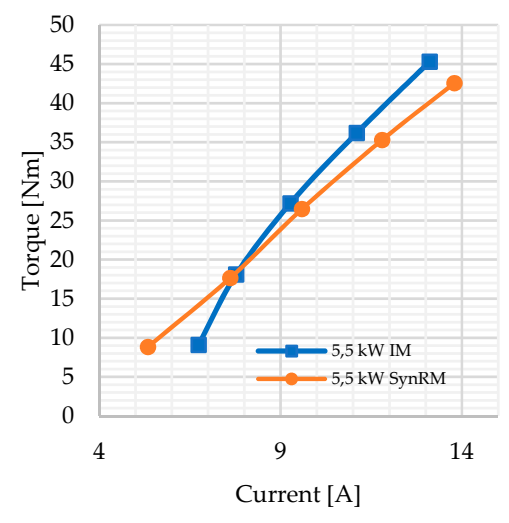

(c)

Figure 18. Comparison of Torque vs. Current for (a) $2.2 \mathrm{~kW}$, (b) $4 \mathrm{~kW}$, and (c) $5.5 \mathrm{~kW}$.

IMs perform higher torque values at the same current values as given in Figure 18 since SynRMs have lower power factors. Input power vs. Torque graphs are presented in Figure 19.

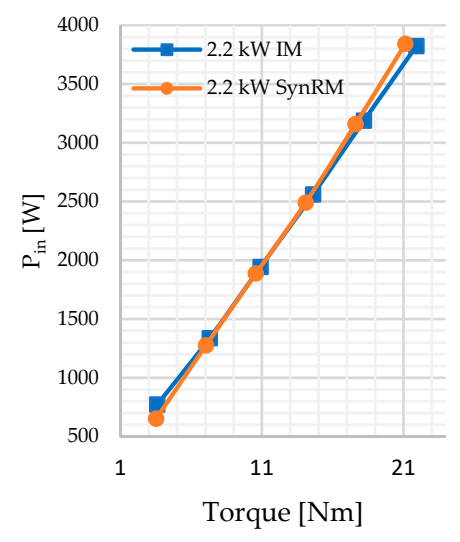

(a)

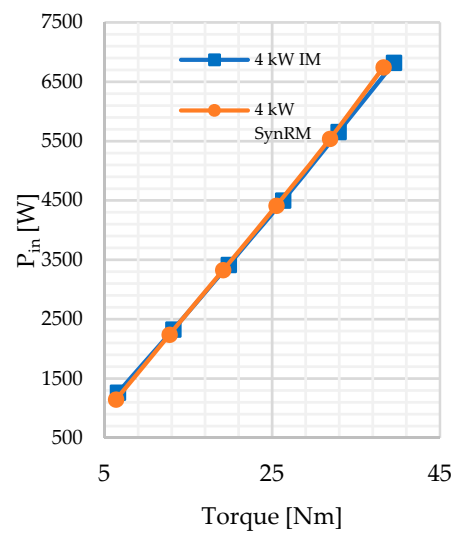

(b)

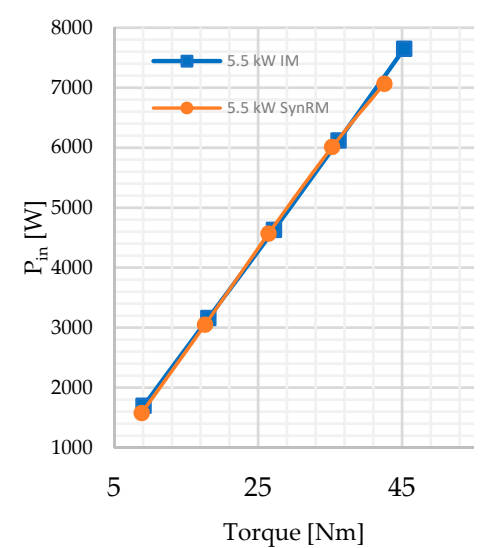

(c)

Figure 19. Comparison of Input Power vs. Torque for (a) $2.2 \mathrm{~kW}$, (b) $4 \mathrm{~kW}$, and (c) $5.5 \mathrm{~kW}$.

The torque vs. total losses of the motors are given in Figure 20. The total losses of the SynRMs are less than those of the IMs for the same torque values. 


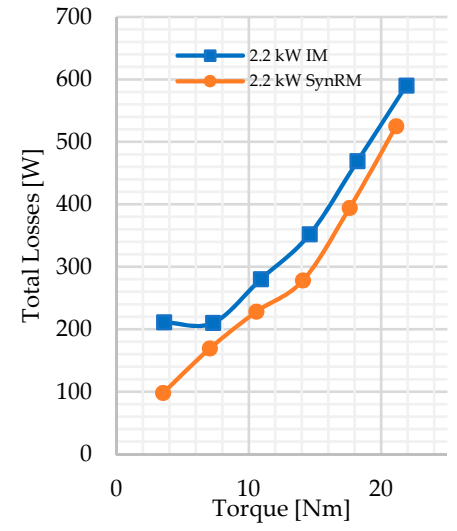

(a)

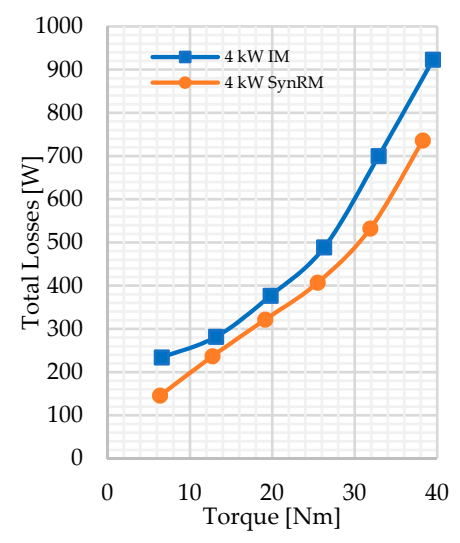

(b)

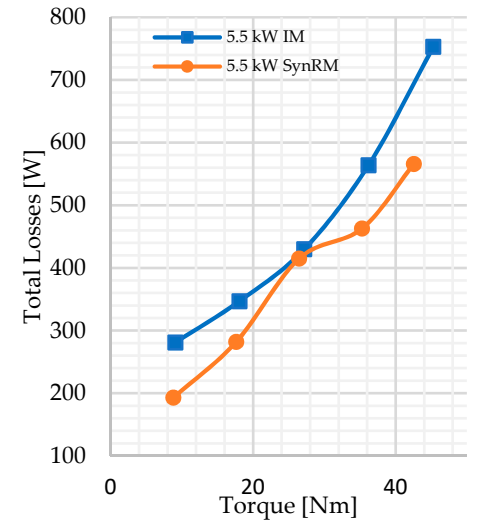

(c)

Figure 20. Comparison of Total Losses vs. Torque for (a) $2.2 \mathrm{~kW}$, (b) $4 \mathrm{~kW}$, and (c) $5.5 \mathrm{~kW}$.

\subsection{Active Material}

The synchronous reluctance motors were designed while keeping the same stator design, ampere-turns, and stack heights, with the reference induction motors for all three power ranges in this study as indicated above sections. The main difference is the rotor frames between the reference induction motors and the newly designed synchronous reluctance motors. All other active materials, such as laminations and stator conductors, are kept the same, except for the rotor conductor. The rotor of an induction motor includes magnetic steel and aluminum alloy as an active material. The rotor of a synchronous reluctance motor includes only magnetic steel. Since the stator lamination and stator windings are kept the same, the only difference between the IM and SynRM motors' material cost is on the rotor side. The active material usage is shown for both of the motors in Table 19. This will give an idea about material costs of the motors.

Table 19. Rotor Materials of IM \& SynRM (in pu).

\begin{tabular}{cccccccc}
\hline \multirow{2}{*}{ Material } & \multicolumn{2}{c}{$\mathbf{2 . 2} \mathbf{~ k W}$} & \multicolumn{2}{c}{$\mathbf{4} \mathbf{~ k W}$} & \multicolumn{2}{c}{$5 \mathbf{5 . 5} \mathbf{k W}$} \\
\cline { 2 - 7 } & IM & SynRM & IM & SynRM & IM & SynRM \\
\hline Magnetic steel & 0.79 & 0.79 & 0.79 & 0.79 & 0.88 & 0.88 \\
Aluminum conductor & 0.21 & - & 0.21 & - & 0.11 & - \\
Total active material at rotor & 1 & 0.79 & 1 & 0.79 & 1 & 0.88 \\
\hline
\end{tabular}

\subsection{Thermal Performance}

The thermal regime of the windings should be reached before applying the performance tests. The thermal test is performed at the nominal load. The ambient and winding temperatures are measured before starting the test. The motor should be operated at the rated load until the winding temperature does not change at $1^{\circ} \mathrm{K}$ or $1^{\circ} \mathrm{C}$ in a half hour measurement period. The motor reaches the thermal steady state regime if this condition is satisfied. All the electrical, mechanical, and thermal motor parameters are recorded, such as input power $P_{\text {in }}(W)$, output torque $T_{\text {out }}(\mathrm{Nm})$, line current $\mathrm{I}_{1}(A)$, phase-to-phase voltage $\mathrm{V}(\mathrm{V})$, speed $\mathrm{n}\left(\mathrm{min}^{-1}\right)$, frequency $\mathrm{f}(\mathrm{Hz})$, stator phase winding resistance $\mathrm{R} 1$ (ohms), and winding temperature $\left({ }^{\circ} \mathrm{C}\right)$.

The thermal analysis for the SynRMs is performed using MOTORCAD software (V10.2.3, Motor Design Limited, Wrexham, UK). The geometry is applied with cooling types and the fin thicknesses as input. The analytical thermal calculations are performed, and the results are compared to those at the rated current values. The initial temperature of the winding for $2.2 \mathrm{~kW}$ SynRM is $22{ }^{\circ} \mathrm{C}$ and it reaches $55^{\circ} \mathrm{C}$ at the end. Similarly, the temperature test is performed for the $2.2 \mathrm{~kW}$ induction motor. The induction motor reaches higher temperature values at the same ratings. The results are given in Table 20. 
Table 20. Winding Temperatures of $2.2 \mathrm{~kW}$ motors.

\begin{tabular}{cccc}
\hline \multicolumn{2}{c}{ SynRM } & \multicolumn{2}{c}{ IM } \\
\hline Parameter & MOTORCAD & Test & Test \\
\hline Temperature $\left({ }^{\circ} \mathrm{C}\right)$ & 56.1 & 55 & 64.1 \\
\hline
\end{tabular}

The MOTORCAD results are shown in Figure 21 for the $2.2 \mathrm{~kW}$ SynRM.

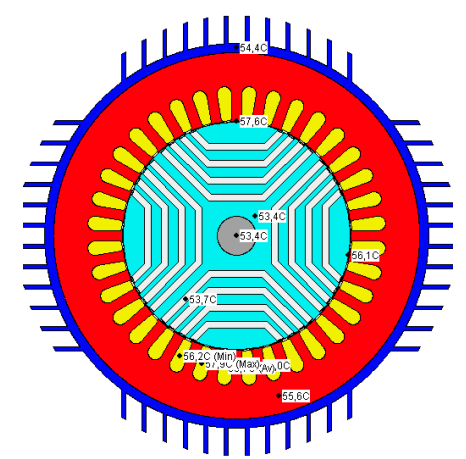

(a)

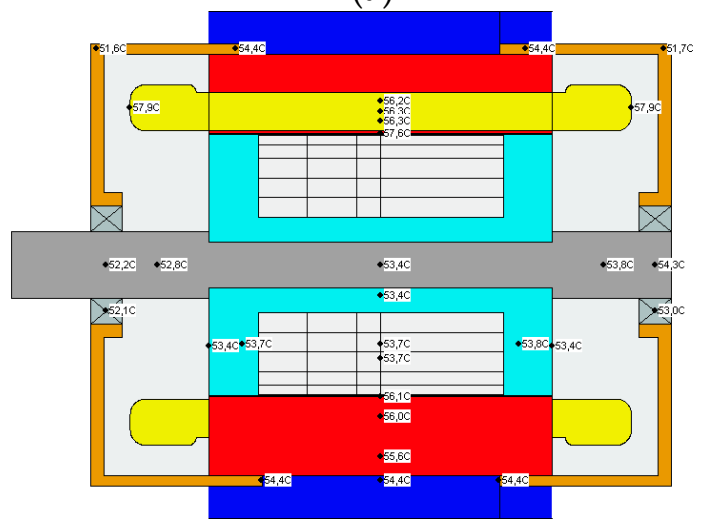

(b)

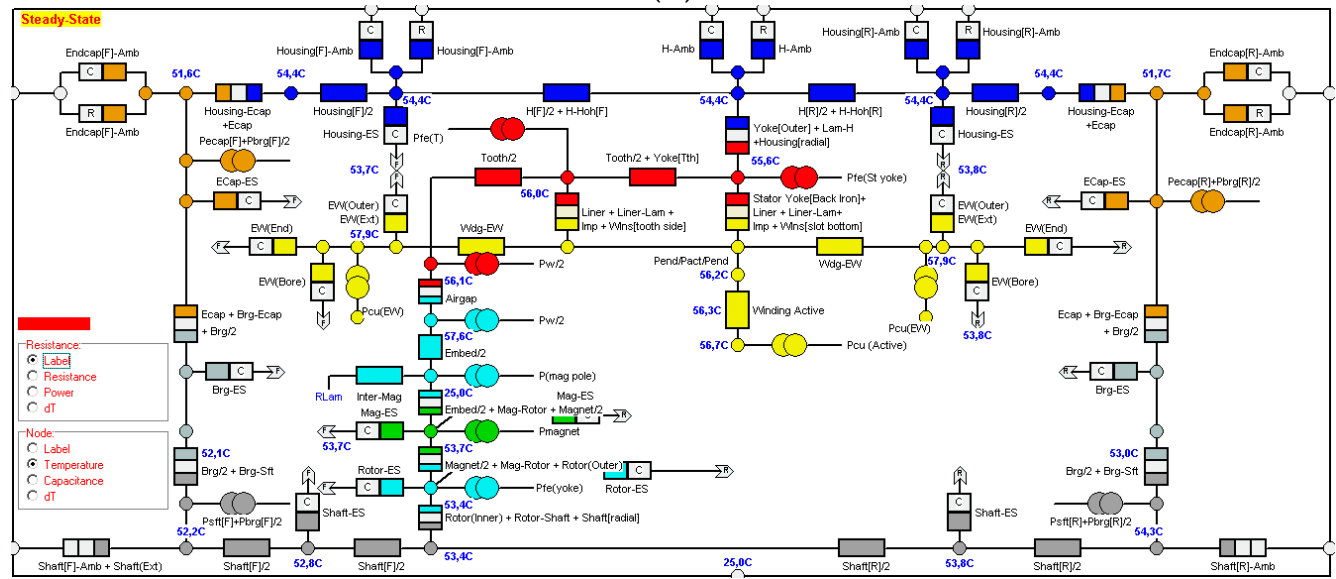

(c)

Figure 21. Thermal analysis of $2.2 \mathrm{~kW}$ SynRM (a) radial, (b) axial, (c) nodal equivalent representation.

The lack of rotor copper bars affects the thermal results and efficiency as well. 


\subsection{Vibration and Comfort Performances}

Since the torque ripple is an important parameter for motor design procedure, after producing prototype SynRM motors, vibration tests are performed. Permitted vibration accelerations are given in IEC 60034-14 standards. The upper limit is defined for the motor producers as $2.5 \mathrm{~m} / \mathrm{s}^{2}$ for free suspension between 56 and 132 frame motors [23]. The vibration and torque ripple comparison of SynRM motors is presented for different power levels in Table 21. The torque ripple results are output of the FEM analysis. It can be seen that the SynRM motors have higher vibration and torque ripple values than those of reference IMs.

Table 21. Vibration and Torque Ripple Comparison.

\begin{tabular}{ccccc}
\hline \multirow{2}{*}{ Power } & \multicolumn{2}{c}{ Vibration $\left(\mathbf{m} / \mathbf{s}^{\mathbf{2}}\right)$} & \multicolumn{2}{c}{ Torque Ripple (\%) } \\
\cline { 2 - 5 } & IM & SynRM & IM & SynRM \\
\hline $2.2 \mathrm{~kW}$ & 0.267 & 1.43 & 13.5 & 18 \\
$4 \mathrm{~kW}$ & 0.273 & 1.67 & 15.2 & 17 \\
$5.5 \mathrm{~kW}$ & 0.316 & 1.82 & 20 & 22 \\
\hline
\end{tabular}

\section{Conclusions}

In low-power industrial applications product groups, efficiency, cost, and power density play an important role when system requirements are considered. In this study, three different power stage induction motors $(2.2 \mathrm{~kW}, 4 \mathrm{~kW}$, and $5.5 \mathrm{~kW})$ are taken as the reference motors. The main aim of this study is to design and make a comparison of synchronous reluctance motors. The main difference between the induction motors and the synchronous reluctance motors is the rotor structure. The stator structure and radial air gap length are kept constant for both IMs and SynRMs. Different types of rotor design parameters are considered to make a complementary design. After the selection of the best models for each power level, the selected models are prototyped and tested for measuring their performance. SynRM has slightly higher efficiency than IM since rotor losses are eliminated. Main drawback of SynRMs are the low-power factors. IMs provides higher torque values at the same current levels and requires lower input power for the same output power.

As a result, considering losses, cost, and power density, the newly designed synchronous reluctance motor prototypes give an alternative compared to the reference induction motors. The stator winding can also be designed for a future work to justify the input voltage levels of SynRMs. Increasing the stack length would be another solution to decrease voltage levels. The reliability, torque ripple, vibration improvements, and power factor optimization are worth investigating further.

Author Contributions: All the authors contributed substantially to the paper. Conceptualization, M.I. and L.T.E.; methodology, M.I. and L.T.E.; software, U.E.D. and N.G.O.; validation, U.E.D., N.G.O., M.I. and L.T.E.; writing—original draft preparation, N.G.O., L.T.E.

Funding: This research was funded by TUBITAK grant number 1140055 and by ITU-AYP-2014-3 Project financially.

Acknowledgments: The authors gratefully thank to Cenap ERTURK and Hakan GEDİK at ARÇELIK Çerkezkoy Plant and CEDRAT, France for supporting the R\&D studies at universities.

Conflicts of Interest: The authors declare no conflict of interest.

\section{References}

1. Kostko, J.K. Polyphase reaction synchronous motors. J. Am. Inst. Electr. Eng. 1923, 42, 1162-1168. [CrossRef]

2. Cruickshank, A.J.O.; Menzies, R.W.; Anderson, A.F. Axially Laminated Anisotropic Rotors for Reluctance Motors. Proc. Inst. Electr. Eng. 1966, 113, 2058-2060. [CrossRef]

3. Cruickshank, A.J.O.; Menzies, R.W.; Anderson, A.F. Theory and performance of reluctance motors with axially laminated anisotropic rotors. Proc. Inst. Electr. Eng. 1971, 118, 887-894. [CrossRef]

4. Honsinger, V.B. The inductances Ld and Lq of reluctance machines. IEEE Trans. Power Appar. Syst. 1971, PAS-90, 298-304. [CrossRef] 
5. Lipo, T. Synchronous Reluctance Machines-A Viable Alternative for AC Drives. Electr. Mach. Power Syst. 1991, 19, 659-671. [CrossRef]

6. Matsuo, T.; Lipo, T.A. Rotor design optimization of synchronous reluctance machine. IEEE Trans. Energy Convers. 1994, 9, 359-365. [CrossRef]

7. Staton, D.A.; Miller, T.J.E.; Wood, S.E. Optimisation of the synchronous reluctance motor geometry. In Proceedings of the 5th International Conference on Electrical Machines and Drives, London, UK, 11-13 September 1991; pp. 156-160.

8. Lagerquist, R.; Boldea, I.; Miller, T.J.E. Sensorless-control of the synchronous reluctance motor. IEEE Trans. Ind. Appl. 1994, 30, 673-682. [CrossRef]

9. Miller, T.J.E.; Hutton, A.; Cossar, C.; Staton, D.A. Design of a synchronous reluctance motor drive. IEEE Trans. Ind. Appl. 1991, 27, 741-749. [CrossRef]

10. Vagati, A.; Canova, A.; Chiampi, M.; Pastorelli, M.; Repetto, M. Design refinement of synchronous reluctance motors through finite-element analysis. IEEE Trans. Ind. Appl. 2000, 36, 1094-1102. [CrossRef]

11. Boglietti, A.; Cavagnino, A.; Pastorelli, M.; Vagati, A. Experimental comparison of induction and synchronous reluctance motors performance. In Proceedings of the Conference Record of 40th IAS Annual Meeting, Hong Kong, China, 2-6 October 2005; pp. 474-479.

12. Germishuizen, J.J.; Van der Merwe, F.S.; Van der Westhuizen, K.; Kamper, M.J. Performance comparison of reluctance synchronous and induction traction drives for electrical multiple units. In Proceedings of the Conference Record of the 2000 IEEE Industry Applications Conference, Rome, Italy, 8-12 October 2000.

13. Staton, D.A.; Miller, T.J.E.; Wood, S.E. Maximising the saliency ratio of the synchronous reluctance motor. IEE Proc. B Electr. Power Appl. 1993, 140, 249-259. [CrossRef]

14. Moghaddam, R.R. Synchronous Reluctance Machine (SynRM) Design. Master's Thesis, The Royal Institute of Technology (KTH), Stockholm, Sweden, 2007.

15. Moghaddam, R.R.; Magnussen, F.; Sadarangani, C. Novel rotor design optimization of synchronous reluctance machine for high torque density. In Proceedings of the 6th IET International Conference on Power Electronics, Machines and Drives (PEMD 2012), Bristol, UK, 27-29 March 2012.

16. Moghaddam, R.R.; Magnussen, F.; Sadarangani, C. Novel rotor design optimization of synchronous reluctance machine for low torque ripple. In Proceedings of the XXth International Conference on Electrical Machines, Marseille, France, 2-5 September 2012; pp. 397-403.

17. Bianchi, N.; Bolognani, S.; Bon, D.; Pré, M.D. Rotor flux-barrier design for torque ripple reduction in synchronous reluctance motors. In Proceedings of the Industry Applications Conference, Tampa, FL, USA, 8-12 October 2006.

18. Lin, C.-H.; Hwang, C.-C. High Performances Design of a Six-Phase Synchronous Reluctance Motor Using Multi-Objective Optimization with Altered Bee Colony Optimization and Taguchi Method. Energies 2018, 11, 2716. [CrossRef]

19. Howard, E.; Kamper, M.J.; Gerber, S. Asymmetric Flux Barrier and Skew Design Optimization of Reluctance Synchronous Machines. IEEE Trans. Ind. Appl. 2015, 51, 3751-3760. [CrossRef]

20. Cupertino, F.; Pellegrino, G.; Gerada, C. Design of Synchronous Reluctance Motors with Multiobjective Optimization Algorithms. IEEE Trans. Ind. Appl. 2014, 50, 3617-3627. [CrossRef]

21. Tap, A.; Xheladini, L.; Yilmaz, M.; Imeryuz, M.; Asan, T.; Ergene, L.T. Comprehensive design and analysis of a PMaSynRM for washing machine applications. IET Electr. Power Appl. 2018, 12, 1311-1319. [CrossRef]

22. Ozcelik, N.G.; Dogru, U.E.; Gedik, H.; Imeryuz, M.; Ergene, L.T. A multi-parameter analysis for rotor design of synchronous reluctance motors. In Proceedings of the XXII International Conference on Electrical Machines, Lausanne, Switzerland, 4-7 September 2016; pp. 664-670.

23. IEC 60034-14. Rotating Electrical Machines_Part 14: Mechanical Vibration of Certain Machines with Shaft Heights $56 \mathrm{~mm}$ and Higher-Measurement, Evaluation and Limits of Vibration Severity; ANSI: New York, NY, USA, 2018.

(C) 2019 by the authors. Licensee MDPI, Basel, Switzerland. This article is an open access article distributed under the terms and conditions of the Creative Commons Attribution (CC BY) license (http://creativecommons.org/licenses/by/4.0/). 